\title{
A summary of twelve months' operation of the new biogas cogeneration set in the WARTA S.A. Waste Treatment Plant in Częstochowa
}

\author{
The paper presents a summary of twelve months' commercial operation of the new biogas cogeneration set with the \\ GE JENBACHER engine, type JMS 316 GS-B.LC, which was installed at the end of December 2008 in the WARTA \\ S.A. Waste Treatment Plant in Czestochowa. The summary of the first six months of operation of this set is discussed \\ in reference [4].
}

Key words: biogas engine, CHP - combined heat and power, industrial operation

\section{Podsumowanie dwunastomiesięcznej eksploatacji nowego biogazowego zespołu kogeneracyjnego w Oczyszczalni Ścieków WARTA S.A. w Częstochowie}

\begin{abstract}
W pracy zaprezentowano podsumowanie dwunastomiesięcznej eksploatacji przemystowej nowego biogazowego zespołu kogeneracyjnego z silnikiem GE JENBACHER typu JMS 316 GS-B.LC zainstalowanego w końcu grudnia 2008 r. w Oczyszczalni Ścieków WARTA S.A. w Częstochowie. Podsumowanie pierwszych sześciu miesięcy eksploatacji tego zespotu omówiono $w$ [4].
\end{abstract}

Słowa kluczowe: silnik biogazowy, energetyka skojarzona, eksploatacja przemysłowa

\section{Introduction}

As early as in the seventies of the past century, The WARTA S.A. Waste Treatment Plant in Częstochowa, and actually its predecessor - the WARTA S.A. Commercial Water Company, undertook, on the initiative of Prof. Karol Cupiał from the Institute of Internal Combustion Engines and Control Engineering of the Częstochowa University of Technology (IMTiTS PCz), Poland's first trials on the utilization of biogas, a by-product of anaerobic sewage sludge fermentation, by using it for supplying piston engine-driven gas cogeneration sets [1]. Those works were initiated by the adaptation of the WOLA DV 6R unsupercharged engine to be double-fuel supplied with biogas and a reduced dose of fluid fuel, and the subsequent versions were adapted to operate on sole biogas as spark-ignition engines. In the seventies, jointly with ZMiN WOLA of Warsaw, the IMTiTS PCz constructed and tested a family of WOLA HENSCHEL engines: a $100 \mathrm{~kW}$ (unsupercharged) 6R, a 200 $\mathrm{kW}$ (unsupercharged) H12V, and a $300 \mathrm{~kW}$ (supercharged) models, in which the engine cooling heat and the exhaust gas heat were also utilized. Based on the positive results of long-lasting operational tests of these engines, carried out at PSW WARTA of Częstochowa, ZMIN WOLA of Warsaw started up their commercial-scale production. In the years 1996-99, the IMTiTS PCz carried out at the WARTA S.A. Waste Treatment Plant the KBN target project no. 9 T12D $00395 \mathrm{C} / 2587$ "The prototype and optimization studies of the $8 \mathrm{~A} 20 \mathrm{G}$ gas engine-driven heat-recovery generating set and its implementation to series production at $\mathrm{H}$. CEGIELSKI-POZNAŃ S.A.”. These efforts resulted in the construction of Poland's largest and most modern heat \& power-generating set with an $8 \mathrm{~A} 20 \mathrm{G}(600 \mathrm{~kW} / 1000 \mathrm{rpm})$

\section{Wprowadzenie}

Oczyszczalnia Ścieków WARTA S.A. w Częstochowie, a właściwie jej poprzedniczka Przemysłowa Spółka Wodna WARTA S.A. w Częstochowie, już w latach siedemdziesiątych ubiegłego wieku, z inicjatywy prof. Karola Cupiała z Instytutu Maszyn Tłokowych Politechniki Częstochowskiej podjęła pierwsze w Polsce próby utylizacji biogazu - produktu ubocznego beztlenowej fermentacji osadów ściekowych poprzez jego wykorzystanie do zasilania gazowych zespołów kogeneracyjnych z silnikami tłokowymi [1]. Prace te zostały zapoczątkowane adaptacją wolnossącego silnika WOLA DV 6R do dwupaliwowego zasilania biogazem i zmniejszoną dawką paliwa płynnego, następne wersje adaptowano do pracy na samym biogazie jako silniki z zapłonem iskrowym. W latach osiemdziesiątych wspólnie z ZMiN WOLA Warszawa IMTiTS PCz skonstruował i przebadał rodzinę silników WOLA HENSCHEL - 6R 100 kW (wolnossący), H12V $200 \mathrm{~kW}$ (wolnossący) i $300 \mathrm{~kW}$ (doładowany), w których utylizowano także ciepło chłodzenia silnika i ciepło spalin. W oparciu o pozytywne wyniki długotrwałych badań eksploatacyjnych tych silników prowadzonych w PSW WARTA w Częstochowie ZMIN WOLA Warszawa uruchomiły ich produkcję przemysłową. W latach 1996-99 IMTiTS PCz zrealizował w Oczyszczalni Ścieków WARTA S.A. w Częstochowie projekt celowy KBN nr 9 T12D 003 95C/2587 „Prototyp i badania optymalizacyjne zespołu prądotwórczego z odzyskiem ciepła napędzanego silnikiem gazowym 8A20G oraz wdrożenie do produkcji seryjnej w H.CEGIELSKI-POZNAŃ S.A.”. W wyniku realizacji tych prac powstał największy i najnowocześniejszy krajowy zespół ciepło- i prądotwórczy z biogazowym silnikiem 8A20G (600 kW/1000 obr/min) 
engine with the recovery of the heat of engine, oil, and blend cooling and the exhaust gas heat $[5,6]$. The cogeneration set with this engine was commercially operated in the WARTA S.A. Waste Treatment Plant in Częstochowa by IMTiTS PCz workers up to 2006 [2], and in 2008 it was sold and substituted with a cogeneration set with a GE JENBACHER engine of larger power.

\section{The Cogeneration Set with the GE JENBACHER JMS 316 GS-B.LC Biogas Engine}

The WARTA S.A. Waste Treatment Plant receives each day averagely approx. $50000 \mathrm{~m}^{3}$ of sewage and retains approx. 500-600 $\mathrm{m}^{3}$ of crude sewage sludge, and produces approx. $6500 \mathrm{~m}^{3}$ of biogas (about $272 \mathrm{~m}^{3} / \mathrm{h}$ ) of a calorific value of approx. $23 \mathrm{MJ} / \mathrm{m}^{3}$ [19].

Currently, after the modernization of the biological, sludge, and gas parts, carried out in recent years, and including [19]: increasing the capacity of the bioreactors, introducing a sewage recycling system to them and changing the system of their aeration; building of a new, fourth closed $2900 \mathrm{~m}^{3}$-capacity fermentation chamber, thus increasing their previous capacity by $30 \%$; changing the sludge agitation method; construction of chambers for gravity agitation and thickening of excessive and primary sludges; installation of a flexible double-shelled biogas gasholder of a capacity of $2150 \mathrm{~m}^{3}$; a new biogas cogeneration set with a GE JENBACHER JMS 316 GS-B.LC engine of an electric power of $828 \mathrm{~kW}$ and a thermal power of $870 \mathrm{~kW}$ was also purchased and started up in the renovated building (Fig. 1) in which the previous cogeneration set was operated. The supplier of the engine was KWE Technika Energetyczna Sp. z o.o. of Bielsko-Biala, the Authorized Representative of GE JENBACHER Gas Engines Division for Poland. The total cost of this investment project, which was carried out within 7 months, closed at a sum of 3.7 million PLN [19].

As a result of the modernization carried out, in addition to ecological effect, such as a significant reduction of the quantities of nitrogen and phosphorus, and thus the compounds responsible for the eutrophication of the Warta river aquatic environment, the biogas production was increased by approx. $40 \%$, up to a level of about 2.2 million $\mathrm{m}^{3}$ annually [19]. A flow sheet of the WARTA S.A. Waste Treatment Plant in Częstochowa is shown in Fig. 2.

The crude sewage sludge - thickened in the funnels of primary settling tanks to a dry matter content of approx. 5\%, and the excessive sewage sludge - formed at the biological stage after thickening to a dry matter content of approx. $5-6 \%$ in the mechanical thickener, are routed to separate closed fermentation chambers, where, at a temperature of $35-37^{\circ} \mathrm{C}$, they undergo anaerobic methane fermentation, and thus produced biogas is utilized in the GE JENBACHER JMS 316 GS-B.LC Engine Cogeneration Set, which was commenced to be operated by the Treatment Plant at the end of 2008. This is a typical combined heat and power (CHP) plant, which generates electric energy and heat at a source of the gaseous fuel and in a place, where it is demanded. A drier for dewatered sewage sludge coming from the presses, z odzyskiem ciepła chłodzenia silnika, oleju, mieszanki i ciepła spalin $[5,6]$. Zespół kogeneracyjny z tym silnikiem był eksploatowany przemysłowo w OŚ WARTA S.A. przez pracowników IMTiTS PCz do roku 2006 [2], a w roku 2008 został sprzedany i zastąpiono go zespołem kogeneracyjnym z silnikiem GE JENBACHER większej mocy.

\section{Zespól kogeneracyjny z silnikiem biogazowym GE JENBACHER JMS 316 GS-B.LC}

Oczyszczalnia Ścieków WARTA S.A. w Częstochowie przyjmuje dobowo średnio ok. $50000 \mathrm{~m}^{3}$ ścieków, zatrzymuje ok. 500-600 $\mathrm{m}^{3}$ osadu surowego oraz produkuje ok. $6500 \mathrm{~m}^{3}$ biogazu (ok. $272 \mathrm{~m}^{3} / \mathrm{h}$ ) o wartości opałowej ok. 23 $\mathrm{MJ} / \mathrm{m}^{3}$ [19].

Obecnie po przeprowadzonej w ostatnich latach modernizacji części biologicznej, osadowej i gazowej obejmującej m.in. [19]: zwiększenie pojemności bioreaktorów, wprowadzenie w nich systemu recyrkulacji ścieków i zmianę systemu ich napowietrzania, budowę nowej, czwartej zamkniętej komory fermentacyjnej o pojemności $2900 \mathrm{~m}^{3}$ powiększającej dotychczasową ich pojemność o 30\%, zmianę sposobu mieszania osadów, budowę komór do grawitacyjnego mieszania i zagęszczania osadów nadmiernych i wstępnych, instalację elastycznego dwupowłokowego zbiornika biogazu o pojemności $2150 \mathrm{~m}^{3}$, zakupiono także i uruchomiono - w zmodernizowanym budynku (rys. 1), w którym eksploatowano poprzedni zespół kogeneracyjny - nowy biogazowy zespół kogeneracyjny z silnikiem GE JENBACHER JMS 316 GS-B.LC o mocy elektrycznej 828 kW i mocy cieplnej 870 kW. Dostawcą silnika była firma KWE Technika Energetyczna Sp. z o.o. - Autoryzowany Przedstawiciel w Polsce GE JENBACHER Gas Engines Division z Bielska-Białej. Koszt całkowity tej inwestycji, zrealizowanej o okresie 7 miesięcy, zamknął się kwotą 3,7 mln zł [19].

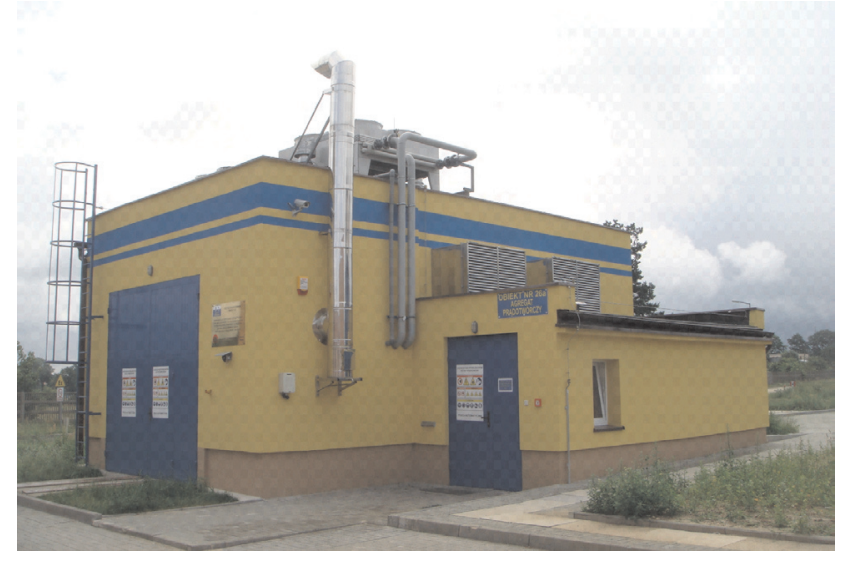

Fig. 1. The thermal-electric power station facility of the WARTA S.A. Waste Treatment Plant in Częstochowa, in which the GE JENBACHER JMS 316 GS-B.LC Engine Biogas Cogeneration Set is installed

Rys. 1. Budynek elektrociepłowni w Oczyszczalni Ścieków WARTA S.A. w Częstochowie w którym zainstalowano biogazowy zespół kogeneracyjny z silnikiem GE JENBACHER JMS 316 GS-B.LC

W wyniku przeprowadzonej modernizacji, oprócz czysto ekologicznych efektów, jak znaczące zmniejszenie ilości azotu i fosforu, a więc związków biogennych odpowie- 


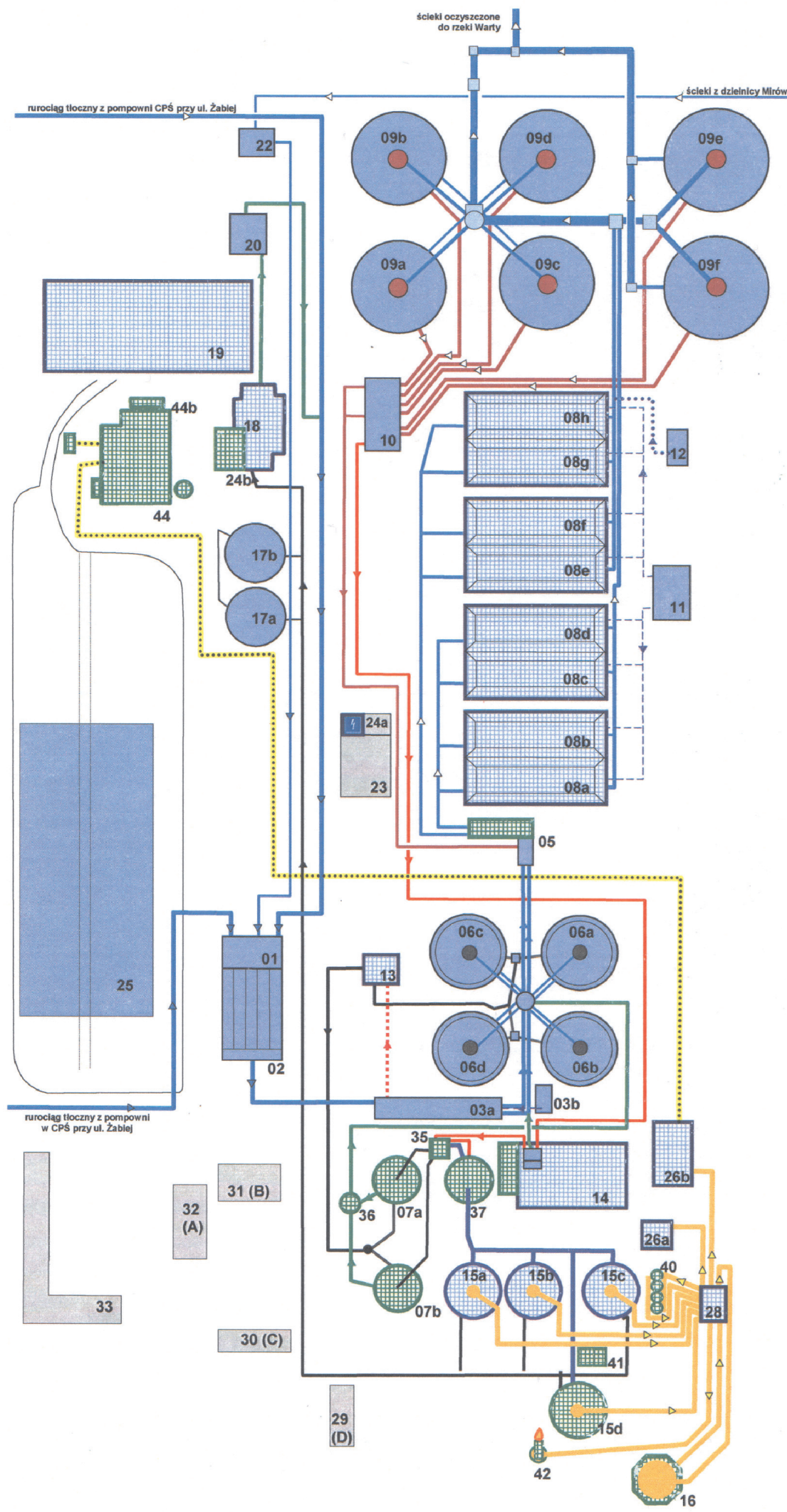

\section{Legenda:}

obiekty technologiczne....

obiekty zmodernizowane

obiekty nowowybudowane

obiekty pomocnicze

ścieki .....

osad recyrkulowany .

osad nadmierny...

osad mieszany

osad przefermentowany

wody osadowe.

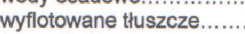

reagenty.

biogaz

gaz ziemny GZ50 $\ldots \ldots \ldots \ldots . . \ldots \ldots$

01 - Budynek krat

02 - Piaskownik poziomy

03a - Odtłuszczacz napowietrzany

03b - Stacja dmuchaw odtłuszczacza

05 - komora rozdziału $\mathrm{K} 7$

06a - 06d - osadniki wstępne

07a, 07b - Zagęszczacze grawitacyjne osadu

$08 \mathrm{a}-08 \mathrm{~h}$ - reaktory biologiczne

09a - $09 f$ - osadniki wtórne

10 - Pompownia recyrkulatu

11 - Stacja dmuchaw

12 - Stacja koagulantu (PIX)

13 - Pompownia osadu surowego i truszczów

14-Maszynownia WKF

$15 a-15 d-$ Wydzielone Komory Fermentacyjne

16 - Zbiornik biogazu ( $z$ podwójna przepona)

17a, 17b - komory fermentacyjne: OKF-y

18 - Stacja mechanicznego odwadniania osadu

19 - plac odbioru osadu z torowiskiem

20 - Pompownia ścién 2 to

20- Pompownia scieków i odcieków

22 - Pompownia ścieków z Mirowa

23 - pomieszczenie socjalne pracowników

$24 a$ - Stacja transformatorowo-rozdzielcza
$24 \mathrm{~b}$ - Stacja transformatorowo-rozdzielcza

$24 \mathrm{~b}$ - Stacja transform
25 - poletka osadowe

26 - poletka osadowe

$26 \mathrm{~b}$ - Kotłownia

28 - Węzeł rozdzielczo - pomiarowy biogazu

29 - Budynek ${ }_{n} \mathrm{D}$

30 - Budynek ${ }_{n} \mathrm{C}$

31 - Budynek "B" Centralnej Dyspozytorni

(stacje robocze SKCD z tablica synoptyczna)

32 - Budynek „A” Administracyjno-Laboratoryjny

(Siedziba Zarządu O. Ś. "WARTA" S. A.)

33 - budynki warsztatowe i garażowe

35 - Pompownia osadu wstępnego

zagęszczonego

36 - Pompownia cieczy nadosadowej

37 - Zbiornik osadu zmieszanego

40 - odsiarczalniki biogazu

41 - trzon komunikacyjny WKF-ów

42 - Pochodnia biogazu

44 - Suszarnia osadu

$44 \mathrm{~b}$ - Zbiornik osadu dowożonego

Fig. 2. Flow sheet of the WARTA S.A. Waste Treatment Plant in Częstochowa [16]

Rys. 2. Schemat technologiczny Oczyszczalni Ścieków WARTA S.A. w Częstochowie [16]

with an initial dry matter content of $17-30 \%$ [11], operates in the Waste Treatment Plant. The product of the installation is a granulate of a dry matter content of $\min .90 \%$ and a grain size of $1-10 \mathrm{~mm}$. The process of drying at $220-280^{\circ} \mathrm{C}$ is conducted by an indirect method in vertical shelf drying \& dzialnych za eutrofizację środowiska wodnego rzeki Warty, zwiększono o ok. 40\% produkcję biogazu, do poziomu ok. 2,2 $\mathrm{mln} \mathrm{m}^{3}$ rocznie [19].

Schemat technologiczny OŚ WARTA S.A. w Częstochowie przedstawiono na rys. 2 . 
granulating units incorporated in two lines, each of a capacity of $41 \mathrm{~m}^{3} / 24 \mathrm{hrs}$, with the use of mineral oil as the heat carrier, for the heating of which natural gas is used, while the reserve fuel being light fuel oil. The implementation of the new technology by KEPPEL-SEGHERS has brought about the effect [19], whereby only 4000 tons of sewage sludge, and in a maximally dried and hygienized form, too, get through to the natural environment per year, instead of the previous 22,000 tons of environmentally noxious and hard utilizable sewage sludge (in a "cake-like" form). Moreover, dried and granulated sewage sludge is an energy raw-material, with a calorific value of $10.5-11.2 \mathrm{MJ} / \mathrm{kg}[3,19]$, which is comparable to that of brown coal.

In the framework of the research \& development project no. R10 01902 entitled "The piston combustion engine in the sewage sludge gasification installation", which is being currently carried out, the IMTITS PCz is conducting investigation into the possibility of gasifying this granulate and utilizing thus obtained gas as a fuel for supplying the piston engine generating set [3].

The GE JENBACHER JMS 316 GS-B.LC Biogas Engine [10] is a dive unit for the gas cogeneration set (Fig. 3) that generates electric energy and recovers heat from the systems
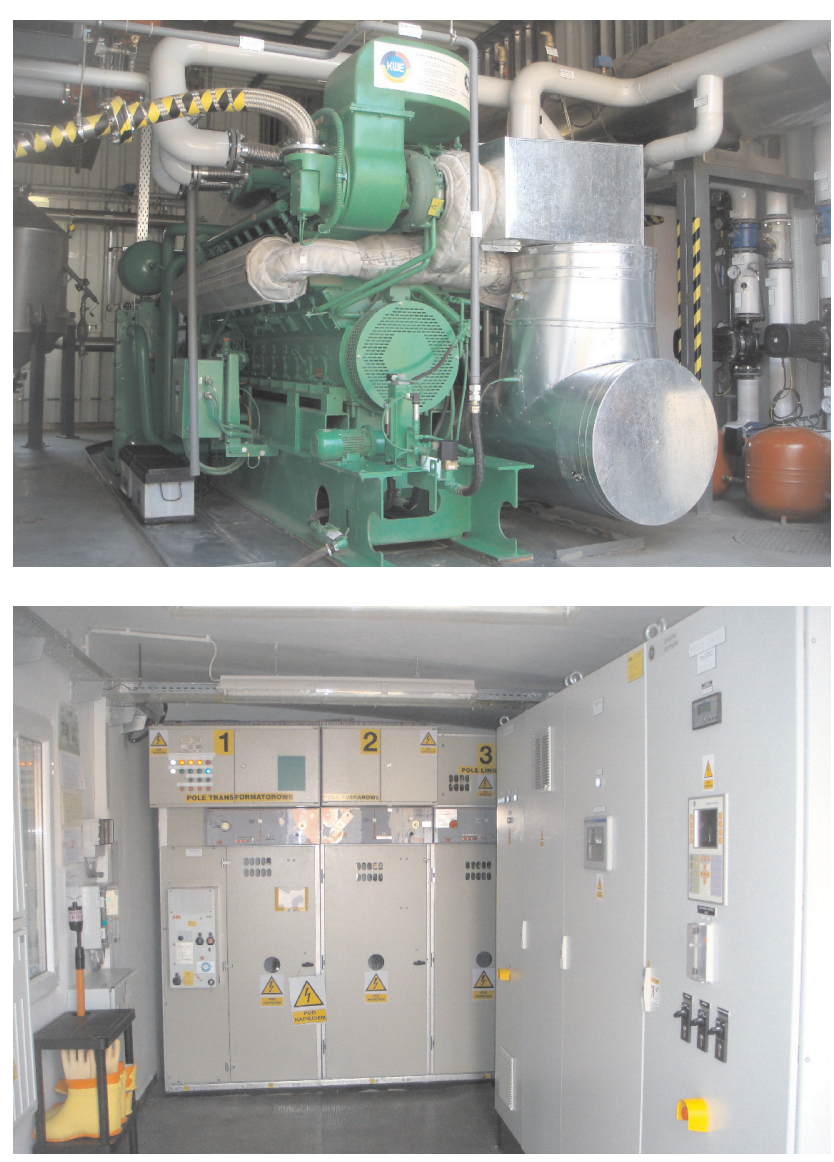

Fig. 3. The GE JENBACHER JMS 316 GS-B.LC Engine Biogas Coge-neration Set installed in the WARTA S.A. Waste Treatment Plant in Częstochowa

Rys. 3. Biogazowy zespół kogeneracyjny z silnikiem GE JENBACHER JMS 316 GS-B.LC zainstalowany w Oczyszczalni Ścieków WARTA S.A. $w$ Czestochowie
Osad surowy - zagęszczony w lejach osadników wstępnych do zawartości ok. 5\% suchej masy i osad czynny nadmierny - powstający w stopniu biologicznym po zagęszczeniu do ok. 5-6\% suchej masy w zagęszczaczu mechanicznym są kierowane do wydzielonych zamkniętych komór fermentacyjnych, gdzie w temp. $35-37^{\circ} \mathrm{C}$ poddawane są beztlenowej fermentacji metanowej, a wytworzony biogaz utylizowany jest w zespole kogeneracyjnym z silnikiem GE JENBACHER JMS 316 GS-B.LC, którego eksploatację oczyszczalnia rozpoczęła w ostatnich dniach 2008 roku. Jest to typowa instalacja energetyki skojarzonej CHP wytwarzająca energię elektryczną i ciepło w źródle paliwa gazowego i w miejscu zapotrzebowania. W oczyszczalni ścieków pracuje suszarnia odwodnionego osadu ściekowego pochodzącego z pras o początkowej zawartości suchej masy $17-30 \%$ [11]. Produktem instalacji jest granulat o zawartości suchej masy min. $90 \%$ i wielkości ziaren 1-10 $\mathrm{mm}$. Proces suszenia w temp. $220-280^{\circ} \mathrm{C}$ jest prowadzony metodą przeponową w pionowych półkowych suszarkogranularkach zabudowanych w dwóch liniach o wydajności $41 \mathrm{~m}^{3} /$ dobę każda, przy zastosowaniu oleju mineralnego jako nośnika ciepła do którego podgrzania wykorzystuje się gaz ziemny, zaś paliwem rezerwowym olej opałowy lekki. Zastosowanie nowoczesnej technologii firmy KEPPEL-SEGHERS spowodowało [19], że do środowiska trafia rocznie zamiast 22000 t uciążliwych dla środowiska i trudnych do zutylizowania osadów ściekowych (w postaci „plackowatej") jedynie $4000 \mathrm{t}$ i to w postaci maksymalnie wysuszonej i zhigienizowanej. Ponadto osuszony i zgranulowany osad ściekowy jest surowcem energetycznym o kaloryczności porównywalnej z węglem brunatnym - wartość opałowa $10,5-11,2 \mathrm{MJ} / \mathrm{kg}[3,19]$.

IMTiTS PCz w ramach realizowanego obecnie projektu badawczo-rozwojowego nr R10 01902 nt. , Tłokowy silnik spalinowy w instalacji zgazowania osadu ściekowego", prowadzi badania dotyczące możliwości zgazowania tego granulatu i wykorzystania pozyskanego gazu jako paliwa do zasilania zespołu prądotwórczego z silnikiem tłokowym [3].

Biogazowy silnik GE JENBACHER JMS 316 GS-B. LC [10] jest jednostką napędową gazowego zespołu kogeneracyjnego (rys. 3) wytwarzającego energię elektryczną oraz odzyskującego ciepło z układów: chłodzenia silnika, oleju smarującego, chłodzenia mieszanki palnej oraz ciepło unoszone przez spaliny. Jest to biogazowy, 16-cylindrowy, doładowany silnik ZI JENBACHER serii 3 w układzie V $\left(70^{\circ}\right)$ wyposażony w system regulacji składu mieszanki palnej LEANOX ${ }^{\circledR} \mathrm{z}$ katalizatorem utleniającym CO. Silnik ten napędza samowzbudny synchroniczny generator trójfazowy AvK DIG 110 i/4 (1090 kVA/864 kWe/6,3 kV/1500 obr/min) firmy Cummins Generator Technologies Germany $\mathrm{GmbH}[10]$.

Silnik tłokowy spełnia aktualnie obowiązujące limity emisji spalin dla stacjonarnych biogazowych silników ZI zawarte w przepisach TA-Luft 2002 [8].

Podstawowe dane techniczne zespołu CHP z silnikiem GE JENBACHER JMS 316 GS-B.LC zamieszczono w tabeli 1 . 
of engine and lubricating oil cooling, air-fuel mixture cooling, and heat carried away with the exhaust gas. This is a biogas 16-cylinder supercharged ZI JENBACHER engine, series 3 , of $\mathrm{V}$-type $\left(70^{\circ} \mathrm{C}\right)$, equipped with a LEANOX ${ }^{\circledR}$ air-fuel mixture composition regulation system with a $\mathrm{CO}$ oxidation catalyst. This engine drives an AvK DIG $110 \mathrm{i} / 4$ (1090 kVA/864 kWe/6.3 kV/1500 rpm) self-excited synchronous three-phase generator supplied by Cummins Generator Technologies Germany GmbH [10].

The basic technical specifications of the CHP set with the GE JENBACHER JMS 316 GS-B.LC engine are given in Table 1.
Silnik ma chłodzone wodą, dwuzaworowe głowice oddzielne dla poszczególnych cylindrów. Zawory wlotowe i wylotowe wyposażone są w układy obrotowe - Rotocap zmniejszające zużycie zespołu zawór-gniazdo zaworowe. Wał korbowy osadzony jest na dziewięciu łożyskach. Silnik wyposażony jest w thumik drgań skrętnych wału korbowego. Kute, hartowane i utwardzane korbowody mają skośnie dzielone stopy. Tłoki ze stopów lekkich mają w denku kanał chłodzenia olejem i są uszczelniane trzema pierścieniami. Wałek rozrządu łożyskowany w dziewięciu punktach jest napędzany od wału korbowego za pośrednictwem kół zębatych. Silnik wyposażony jest w standardowy trakt gazowy

Table 1. Basic technical specifications of the CHP set with the GE JENBACHER JMS 316 GS-B.LC engine [10]

Tabela 1. Podstawowe dane techniczne zespolu CHP z silnikiem GE JENBACHER JMS 316 GS-B.LC [10]

\begin{tabular}{|c|c|c|}
\hline Specification/wyszczególnienie & $\begin{array}{c}\text { Unit/ } \\
\text { Jednostka }\end{array}$ & $\begin{array}{l}\text { Value/ } \\
\text { Wartość }\end{array}$ \\
\hline Number of cylinders/liczba cylindrów & - & 16 \\
\hline Engine capacity/pojemność silnika & $\mathrm{dm}^{3}$ & 38.934 \\
\hline Cylinder bore/średnica cylindra & $\mathrm{mm}$ & 135 \\
\hline Piston stroke/skok tloka & $\mathrm{mm}$ & 170 \\
\hline Compression ratio/stopień sprężania & - & 12.5 \\
\hline Rotational speed - rated/prędkość obrotowa - znamionowa & rpm & 1500 \\
\hline Average effective pressure/średnie ciśnienie efektywne & bar & 17.70 \\
\hline Average piston velocity/średnia prędkość tłoka & $\mathrm{m} / \mathrm{s}$ & 8.5 \\
\hline Mechanical output power/moc wyjściowa mechaniczna & $\mathrm{kW}$ & 861 \\
\hline Electric output power $($ at $\cos \varphi=1.00) /$ moc wyjściowa elektryczna $($ przy $\cos \varphi=1,00)$ & $\mathrm{kW}$ & 828 \\
\hline $\begin{array}{l}\text { Air-fuel mixture/water heat exchanger power, } \pm 8 \% \text { level } 1 / \text { level } 2 / \text { moc wymiennika ciepla mieszanka/woda } \pm 8 \% \\
1 \text { stopień/2 stopień }\end{array}$ & $\mathrm{kW}$ & $131 / 38$ \\
\hline Oil/water heat exchanger power, $\pm 8 \%$ /moc wymiennika ciepła olej/woda $\pm 8 \%$ & $\mathrm{~kW}$ & 95 \\
\hline $\begin{array}{l}\text { Engine cooling warm water/process water heat exchanger power, } 8 \% / \text { moc wymiennika ciepła woda chłodzaca } \\
\text { silnik-woda technologiczna } 8 \%\end{array}$ & $\mathrm{~kW}$ & 253 \\
\hline $\begin{array}{l}\text { Exhaust gas/process water heat exchanger power, } \pm 8 \% / \text { moc wymiennika ciepła spaliny-woda } \\
\text { technologiczna } \pm 8 \%\end{array}$ & $\mathrm{~kW}$ & 391 \\
\hline Total effective thermal power, $\pm 8 \% /$ calkowita użyteczna moc cieplna $\pm 8 \%$ & $\mathrm{~kW}$ & 870 \\
\hline Radiation heat/ciepto radiacji & $\mathrm{kW}$ & 68 \\
\hline Electric efficiency of the set/sprawność elektryczna zespolu & $\%$ & 39.6 \\
\hline Overall efficiency/sprawność calkowita & $\%$ & 81.2 \\
\hline $\begin{array}{l}\text { Engine efficiency loss - per each } 100 \mathrm{~m} \text { of altitude over } 500 \mathrm{~m} \text { above sea level/strata sprawności silnika - na } \\
\text { każde } 100 \text { m ponad } 500 \text { m n.p.m. }\end{array}$ & $\%$ & 0.7 \\
\hline Engine efficiency loss - per $1^{\circ} \mathrm{C}$ above $25^{\circ} \mathrm{C} /$ strata sprawności silnika-na każdy $1^{\circ} \mathrm{C}$ ponad $25^{\circ} \mathrm{C}$ & $\%$ & 0.5 \\
\hline Oil working pressure/ciśnienie robocze oleju & bar & $4-5$ \\
\hline $\begin{array}{l}\text { Cooling water temperature on exit from the engine at full load/temp. wody chłodzącej na wyjściu z silnika przy } \\
\text { petnym obciqżeniu }\end{array}$ & ${ }^{\circ} \mathrm{C}$ & 90 \\
\hline Dry/wet engine / CHP set mass/masa silnika (suchy/mokry)/zespolu CHP & $\mathrm{kg}$ & $4000 / 4490 / 10,900$ \\
\hline Engine/CHP set length/dlugość silnika/zespolu CHP & $\mathrm{mm}$ & $2860 / 5882$ \\
\hline Engine/CHP set width/szerokość silnika/zespołu CHP & $\mathrm{mm}$ & $1340 / 1958$ \\
\hline Engine/CHP set height/wysokość silnika/zespolu CHP & $\mathrm{mm}$ & $1800 / 2240$ \\
\hline Operational oil consumption/eksploatacyjne zużycie oleju & $\mathrm{g} / \mathrm{kWh}$ & 0.2 \\
\hline Lubrication system capacity/pojemność układu smarowania & $\mathrm{dm}^{3}$ & 300 \\
\hline Cooling system capacity/pojemność układu chłodzenia & $\mathrm{dm}^{3}$ & 120 \\
\hline $\begin{array}{l}\mathrm{NO}_{x} \text { emission (dry exhaust gas at } 5 \% \mathrm{O}_{2}-\text { with } 50 \% \text { load) } / \text { Emisja } \mathrm{NO}_{x} \text { (spaliny suche przy } 5 \% \mathrm{O}_{2}-\text { przy } 50 \% \\
\text { obciążenia) }\end{array}$ & $\mathrm{Mg} / \mathrm{m}^{3}$ & 500 \\
\hline $\begin{array}{l}\mathrm{CO} \text { emission (dry exhaust gas at } 5 \% \mathrm{O}_{2}-\text { with } 50 \% \text { load)/emisja CO (spaliny suche przy } 5 \% \mathrm{O}_{2}-\text { przy } 50 \% \\
\text { obciążenia) }\end{array}$ & $\mathrm{Mg} / \mathrm{m}^{3}$ & 300 \\
\hline
\end{tabular}


The piston engine currently meets the exhaust has emission limits applicable to stationary biogas ZI engines, as specified in the TA-Luft 2002 code [8].

The engine has two-valve water-cooled heads, separate for particular cylinders. The inlet and outlet valves are equipped with rotary systems (rotocap) which reduce the wear of the valve-valve seat assembly. The crankshaft is mounted on nine bearings. The engine is equipped with a crankshaft torsional vibration damper. The forged, hardened and toughened connecting-rods have obliquely divided feet. The light alloy pistons have an oil cooling channel in the head, and are sealed with two sings. The distribution shaft is bearing-mounted at nine points and is driven from the crankshaft via gear wheels. The engine is equipped with a standard gas path (Fig. 4) which consists of: a ball valve, a $3 \mu \mathrm{m}$-mesh biogas filter, a preliminary pressure regulator, a safety relief valve, a press-on valve manometer, solenoid valves with a tightness control system, a biogas pressure switch, and a biogas pressure regulator [13].

In the mixer (Fig. 5), the gas fuel is added to the sucked air in a different quantity through the variable servomotoractuated gas diaphragm, whereby the excess air factor, $\lambda$, is changed. This mixer is part of the LEANOX ${ }^{\circledR}$ air-fuel mixture regulation system. The operation of the JENBACHER Gas Engine has been optimized [10] so as to ensure exhaust gas emission as low as possible at engine operation with a lean air-fuel mixture under full load conditions. To achieve the lowest possible exhaust gas emission rates, the direct (rys. 4) który tworzą: zawór kulowy, filtr biogazu o oczkach $3 \mu \mathrm{m}$, wstępny regulator ciśnienia, zawór bezpieczeństwa spustowy, manometr z zaworem naciskowym, zawory elektromagnetyczne z układem kontroli szczelności, wyłącznik ciśnienia biogazu, regulator ciśnienia biogazu [13].

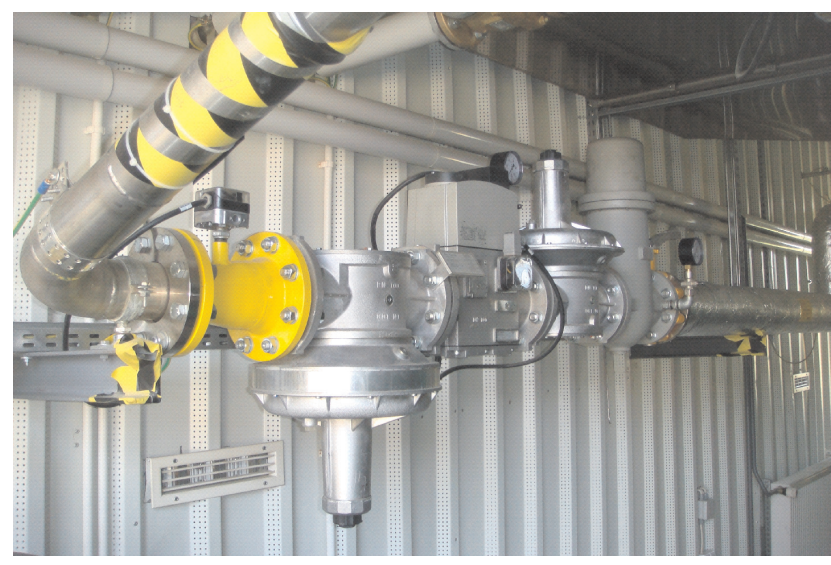

Fig. 4. The gas path of the GE JENBACHER JMS 316 GS-B.LC Biogas Engine

Rys. 4. Ścieżka gazowa silnika biogazowego GE JENBACHER JMS 316 GS-B.LC

W mieszalniku (rys. 5) paliwo gazowe dodawane jest do zassanego powietrza $\mathrm{w}$ różnej ilości poprzez zmienną poruszaną serwomotorem - przesłonę gazu, zmieniając w ten sposób współczynnik nadmiaru powietrza $\lambda$.
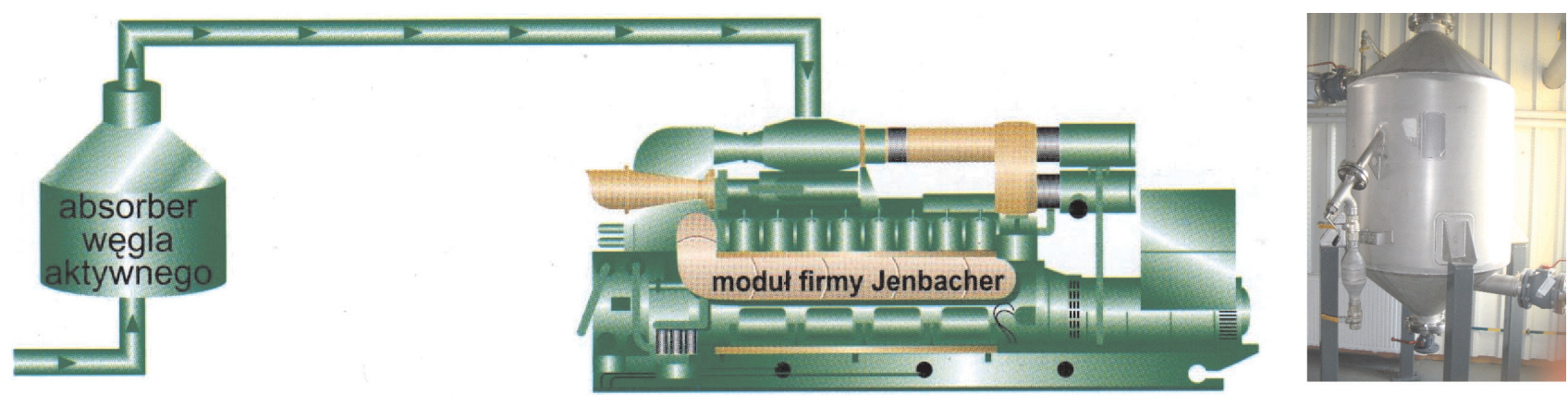

Fig. 5. Schematic of the incorporation the activated carbon absorber into the gas path of the GE JENBACHER JMS 316 GS-B.LC engine [14] and its view

Rys. 5. Schemat włączenia absorbera z węglem aktywnym w trakt gazowy silnika GE JENBACHER JMS 316 GS-B.LC [14] i jego widok

relationship between the $\mathrm{NO}_{\mathrm{x}}$ emission and the excess air factor was used. The LEANOX ${ }^{\circledR}$ regulation system used in these engines does not require the use of an oxygen sensor, i.e. the $\lambda$ probe, which ages as the operation progresses, and it ensures ultimately low exhaust gas emission conditions. The purpose of the LEANOX ${ }^{\circledR}$ regulator is to calculate and set an optimal initial pressure using the current power output and air-gas mixture temperature. A linear relationship between these values is computed automatically by the DIA. NE engine management system. The LEANOX ${ }^{\circledR}$ regulator goes on automatically after the actual power has exceeded a threshold value (of approx. 30\% of the total power output). A PI (proportional-integral) regulator with a stepper motor
Mieszalnik ten stanowi część systemu regulacji składu mieszanki palnej LEANOX®. Sterowanie silnika gazowego JENBACHER zostało zoptymalizowane tak [10], aby zapewnić jak najniższą emisję spalin przy jego pracy na ubogiej mieszance w warunkach pełnego obciążenia. Dla osiągnięcia najniższych z możliwych wskaźników emisji spalin, wykorzystano bezpośrednie powiązanie pomiędzy emisją $\mathrm{NO}_{x}$ a współczynnikiem nadmiaru powietrza. Zastosowany w tych silnikach system regulacji LEANOX ${ }^{\circledR}$ nie wymaga stosowania starzejącego się $\mathrm{w}$ miarę eksploatacji czujnika tlenu - sondy $\lambda$ i zapewnia docelowo niskie warunki emisji spalin. Zadaniem regulatora LEANOX ${ }^{\circledR}$ jest obliczanie i ustawianie optymalnego ciśnienia początkowego 
is employed in the system, which changes the position of the diaphragm in the gas mixer, thus regulating the excess air factor, $\lambda[10]$. The DIA.NE system monitors also the knockless operation of the biogas engine by using vibration sensors placed on each of its blocks. This is a very convenient and user-friendly management \& diagnostic interface, whose LCD screen panel is incorporated in the control cubicle of the CHP set. The turbo-compressor compresses the air-gas mixture and forces it into the mixture cooler. After passing through the turbo-compressor, the exhaust reaches the noise silencer. Then, flowing through the (exhaust gas/water) tubular heat exchanger, it gives up the heat to the process water. The design of the heat exchanger enables it to be put off-line by routing the exhaust gas through its bypass.

The biogas engine is equipped with an IC-922 $(24 \mathrm{~V}$ DC) WOODWARD high-energy microprocessor-controlled ignition module with individual coils for each cylinder. This is system featuring three sensors, each of them for engine rotational speed, crankshaft position, and timing phases. The system allows the spark discharge energy to be regulated in the range of $10-100 \%$. The engine rotational speed, the ignition advance angle and its variations, hours of operation, and the messages of errors in ignition system operation can be displayed on a computer's screen through the RS232 interface. The transmission of data to the PC takes place either via the CAN bus or through the RS232 interface. Should the permissible rotational speed be exceeded, the speed controller cuts out the ignition and the gaseous fuel supply.

To enable a conventional oxidizing catalyst to be used, it is necessary to suitably prepare the biogas by removing its detrimental components. Therefore, in order to comply with the engine manufacturer's requirements for biogas quality [12], an absorber supplied by GE JENBACHER (Fig. 5), filled with a periodically exchanged bed of BA11-type activated coal (approx. $0.8 \mathrm{~m}^{3}$ of $4 \mathrm{~mm}$-diameter grain granulate), was employed in the biogas preparation installation. A criterion for the exchange of the bed is the increase in the resistance to biogas flow up to a level of 30 mbar.

The absorber removes silicon an sulphur compounds, and aromatic hydrocarbon compounds contained in the gas, thus contributing to a reduction of engine wear and a lowering of engine maintenance costs.

The limiting conditions for biogas [14]: relative humidity $<50 \%$; maximum temperature $55^{\circ} \mathrm{C} ; \mathrm{H}_{2} \mathrm{~S}<200 \mathrm{mg} / \mathrm{Nm}^{3}$; total halogen $(\mathrm{Cl}+2 \mathrm{~F})$ contents $<100 \mathrm{mg} / \mathrm{Nm}^{3}$.

The GE JENBACHER JMS 316 GS-B.LC Engine Cogeneration Set is supplied with biogas with the following average composition: $\mathrm{CH}_{4} 60-66 \% ; \mathrm{CO}_{2} 30-34 \% ; \mathrm{H}_{2}$ approx. $4 \% ; \mathrm{N}_{2}$ approx. $2 \%$. In addition, small amounts of carbon monoxide, oxide, hydrocarbons, hydrogen sulphide, ammonia and nitrogen oxide are present in the biogas. The relatively high $\mathrm{CO}_{2}$ content substantially enhances the antiknock properties of the gas, thus making it an attractive fuel for combustion engines.

In the gas distribution centre building, the airTOX Biogassystem instrumentation by FRESENIUS is installed, which serves for the continuous monitoring of chemical z wykorzystaniem bieżącej mocy wyjściowej i temperatury mieszanki powietrze-gaz. Liniowa zależność pomiędzy tymi wartościami jest obliczana automatycznie przez system zarządzania silnikiem DIA.NE. Regulator LEANOX® włącza się automatycznie po przekroczeniu wartości progowej mocy rzeczywistej (ok. 30\% całkowitej mocy wyjściowej). W układzie zastosowano regulator PI (proporcjonalno-całkujący) z silnikiem krokowym, zmieniającym położenie przesłony w mieszalniku gazu, regulując w ten sposób współczynnik nadmiaru powietrza $\lambda[10]$. System DIA.NE nadzoruje także bezstukową pracę silnika biogazowego, korzystając z czujników drgań umieszczonych na każdym z jego bloków. Jest to bardzo wygodny i przyjazny dla obsługi interfejs zarządzająco-diagnostyczny, którego panel z ekranem LCD zabudowany jest w szafie sterowniczej zespołu CHP. Turbosprężarka spręża mieszankę powietrzno-gazową i tłoczy ją do chłodnicy mieszanki. Spaliny po przejściu przez turbosprężarkę trafiają do tłumika hałasu. Następnie, przepływając przez rurowy wymiennik ciepła (spaliny/woda), przekazują ciepło do wody technologicznej. Konstrukcja wymiennika ciepła umożliwia jego wyłączenie z pracy poprzez skierowanie spalin jego obejściem.

Silnik biogazowy wyposażony jest w wysokoenergetyczny, sterowany mikroprocesorowo moduł zapłonowy IC-922 (24V DC) WOODWARD z indywidualnymi cewkami dla każdego cylindra. Jest to instalacja wyposażona w trzy czujniki: prędkości obrotowej silnika, położenia wału korbowego oraz faz rozrządu. Układ ten umożliwia regulację energii wyładowania iskrowego w zakresie 10-100\%. Prędkość obrotowa silnika, kąt wyprzedzenia zapłonu i jego zmiany, godziny pracy, komunikaty błędów w pracy układu zapłonowego mogą być wyświetlane na komputerze poprzez interfejs RS232. Transmisja danych do PC odbywa się za pośrednictwem magistrali CAN lub poprzez interfejs RS232. W przypadku przekroczenia dopuszczalnej prędkości obrotowej regulator prędkości odcina zapłon i dopływ paliwa gazowego. Aby możliwe było zastosowanie konwencjonalnego katalizatora utleniającego, konieczne jest odpowiednie przygotowanie biogazu - usunięcie zawartych w nim szkodliwych składników. Dlatego też w celu spełnienia wymagań producenta silnika odnośnie jakości biogazu [12] w instalacji jego przygotowania zastosowano absorber firmy GE JENBACHER (rys. 5) wypełniony okresowo wymienialnym złożem węgla aktywnego typu BA11 (ok. $0,8 \mathrm{~m} 3$ granulatu o średnicy $4 \mathrm{~mm}$ ). Kryterium jego wymiany jest wzrost oporów przepływu biogazu przez złoże do poziomu 30 mbar.

Absorber usuwa zawarte w gazie związki krzemu, siarki, aromatyczne związki węglowodorów przyczyniając się do zmniejszenia zużycia silnika i obniżenia kosztów jego konserwacji. Warunki graniczne dla biogazu [14]: wilgotność względna $<50 \%$; temperatura maksymalna $55^{\circ} \mathrm{C}$; $\mathrm{H}_{2} \mathrm{~S}<200 \mathrm{mg} / \mathrm{Nm}^{3}$; zawartość łączna halogenu $(\mathrm{Cl}+2 \mathrm{~F})$ $<100 \mathrm{mg} / \mathrm{Nm}^{3}$.

Gazowy zespół kogeneracyjny z silnikiem GE JENBACHER JMS 316 GS-B.LC zasilany jest biogazem o przeciętnym składzie: $\mathrm{CH}_{4} 60-66 \% ; \mathrm{CO}_{2} 30-34 \% ; \mathrm{H}_{2}$ ok. 4\%; $\mathrm{N}_{2}$ ok. 
composition $\left(\mathrm{CH}_{4}, \mathrm{CO}_{2}, \mathrm{O}_{2}, \mathrm{H}_{2} \mathrm{~S}\right)$ of the biogas produced - Fig. 6.

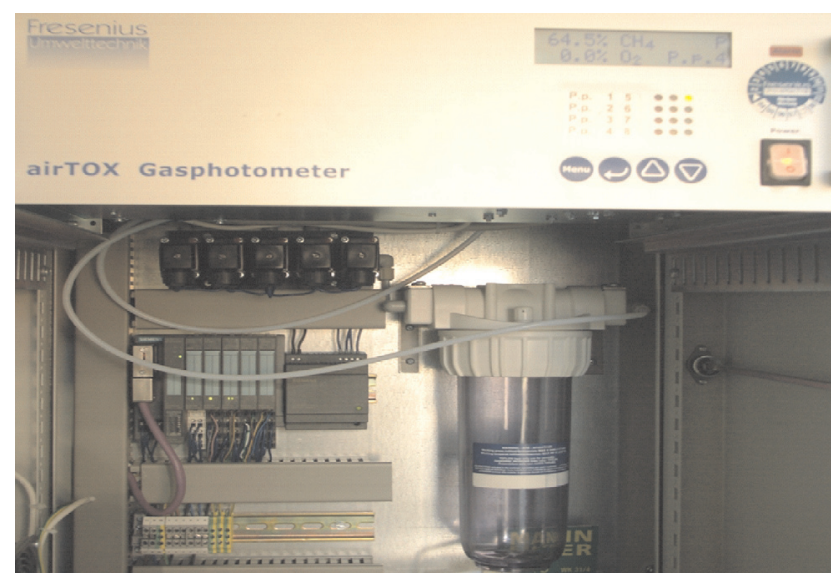

Fig. 6. The airTOX Biogassystem instrumentation by FRESENIUS for the monitoring of biogas chemical composition

Rys. 6. Aparatura airTOX Biogassystem firmy FRESENIUS monitorujaca sklad chemiczny biogazu

The electric power of the cogeneration set is controlled either by setting a manual value from the SCADA overriding system level or through automatic operation allowing for the tariff B23 and the biogas gasholder fill state. In the automatic mode, the system controls the biogas gasholder fill state by attempting to increase the biogas inventory during operation beyond the peak tariff and to operate with the highest possible power within the peak tariff period. Information of which tariff is currently "active" is sent from the SCADA overriding system. Due to the slow process of biogas gasholder filling or emptying, the filling of the gasholder is checked every 10 minutes. If the gasholder is filled in $60 \%$ or more, the electric generator operates at full power. If the gasholder is less than $60 \%$ full and the fill check shows a continued decrease in biogas volume, the generator's power is reduced with $5 \%$ steps until the stored volume stops at a constant level. The increase in fill above $60 \%$ will cause the generator to resume operation at its full power. During cogeneration set operation beyond the peak, the biogas gasholder fill status is checked, similarly as for peak tariff operation, every 10 minutes. In the normal tariff, the system attempts to store the highest possible biogas amount (the complete possible fill), so as to allow electric generator operation at full power in the peak tariff. In the case, where the amount of biogas in the gasholder does not increase, but the gasholder fill has not reached $85 \%$, the generator's power is reduced with $5 \%$ steps. On the other hand, when the gasholder fill has reached $85 \%$, the generator's power is increased with 5\% steps to limit the further increase in the amount of gas.

\section{Technical and operational experience gained so far}

The analysis outlined below concerns a relatively short, since only twelve months' (23.12.2008-31.12.2009), period of operation of the GE JENBACHER JMS 316 GS-B.LC Engine Cogeneration Set, during which it worked for 8450 hours (of which $8258 \mathrm{hrs}$ in 2009).
2\%. Ponadto w biogazie występują niewielkie ilości tlenku węgla, tlenu, węglowodorów, siarkowodoru, amoniaku i tlenku azotu. Stosunkowo duża zawartość $\mathrm{CO}_{2}$ w znaczący sposób podnosi odporność przeciwstukową gazu, czyniąc go atrakcyjnym paliwem dla silników spalinowych. W budynku węzła rozdzielczego gazu zainstalowana jest aparatura airTOX Biogassystem firmy FRESENIUS do prowadzenia ciągłego monitoringu składu chemicznego produkowanego biogazu $\left(\mathrm{CH}_{4}, \mathrm{CO}_{2}, \mathrm{O}_{2}, \mathrm{H}_{2} \mathrm{~S}\right)$ - rys. 6 .

Sterowanie mocą elektryczną zespołu kogeneracyjnego odbywa się poprzez ręczne zadawanie z poziomu systemu nadrzędnego SCADA lub pracę automatyczną z uwzględnieniem taryfy B23 i stanu napełnienia zbiornika biogazu. W trybie automatycznym system kontroluje stan napełnienia zbiornika biogazu starając się zwiększyć zapas biogazu w czasie pracy poza taryfą szczytową, oraz pracując z możliwie wysoką mocą w czasie taryfy szczytowej. Informacje o tym, która taryfa jest aktualnie ,,aktywna”, przesyłana jest z systemu nadrzędnego SCADA. Ze względu na powolny proces napełniania lub opróżniania zbiornika biogazu, jego napełnianie jest kontrolowane, co 10 minut. Jeśli zbiornik jest napełniony w 60\% lub więcej, generator elektryczny pracuje z pełną mocą. Jeśli napełnienie zbiornika jest mniejsze niż $60 \%$ i kontrola napełnienia wykazuje dalszy spadek objętości biogazu moc generatora jest obniżana $\mathrm{w}$ krokach 5\% do chwili, aż zgromadzona objętość zatrzyma się na stałym poziomie. Wzrost napełnienia powyżej $60 \%$ powoduje ponowną pracę generatora z pełną mocą. Podczas pracy zespołu kogeneracyjnego poza szczytem stan napełnienia zbiornika biogazu jest kontrolowany podobnie jak w przypadku pracy w taryfie szczytowej - co 10 minut. W wypadku taryfy normalnej układ dąży do zgromadzenia możliwie dużej ilości biogazu (całkowite możliwe wypełnienie) tak, aby umożliwić pracę generatora elektrycznego z pełną mocą w taryfie szczytowej. W wypadku, kiedy ilość biogazu w zbiorniku nie wzrasta, zaś wypełnienie zbiornika nie osiągnęło 85\%, moc generatora jest obniżana w krokach 5\%. Natomiast w sytuacji, kiedy wypełnienie osiągnęło $85 \%$ moc generatora jest zwiększana w krokach 5\% w celu ograniczenia dalszego przyrostu ilości gazu.

\section{Dotychczasowe doświadczenia techniczno- -eksploatacyjne}

Poniższa analiza dotyczy dotychczasowego stosunkowo krótkiego, bo jedynie dwunastomiesięcznego okresu eksploatacji (23.12.2008 - 31.12.2009 r.) biogazowego zespołu kogeneracyjnego z silnikiem GE JENBACHER JMS 316 GS-B.LC, w którym przepracował on 8450 godzin (w 2009 r. -8258 h).

Producent silnika biogazowego firma GE JENBACHER wymaga do eksploatatora ścisłego przestrzegania planu konserwacji i przeglądów. Dokumentacja techniczna silnika JMS 316 GS-B.LC [10] zawiera szczegółowy ich zakres i harmonogram aż do $60000 \mathrm{~h}$ pracy silnika, czyli do naprawy głównej, po której wszystkie czynności konserwacyjne powtarzają się od początku. Producent silników biogazowych firma GE JENBACHER w „Instrukcji tech- 
The biogas engine's manufacturer, the GE JENBACHER company, requires the Operator to closely follow the maintenance and inspection schedule. The technical documentation of the JMS 316 GS-B.LC engine [10] provides a detailed inspection and maintenance scope and schedule up to 60,000 hours of engine operation, after which point the maintenance activities are repeated from the beginning. In its "Technical instruction - General Conditions - Operation and maintenance" [10], the biogas engine manufacturer, GE JENBACHER, states clearly that the product's properties promised by the manufacturer are only guaranteed on condition that the boundary conditions for GE JENBACHER gas engines, as specified in the Instruction TA no. 1100-0011 [10], be complied with, and that all activities recommended in the Operation Log, whose maintenance is obligatory, be carried out. All service activities on the GE JENBACHER JMS 212 GS-B.LC Engine Biogas Cogeneration Set installation recommended by the manufacturer must be carried out on time and by properly trained personnel only, and the engine operation should proceed without knocking. The time intervals of service activities [10] represent maximum values, which will be achieved with properly run operation and properly performed maintenance. Any extension of the service cycles, e.g. to avoid downtimes of biogas cogeneration sets during heating season, shall not be permitted.

In December 2008, the Service of KWE - Technika Energetyczna carried out training for WARTA Waste Treatment Plant employees in two groups. The first group consisted of shift supervisors, and the second group included individuals foreseen for performing maintenance work. The training session for the first group covered basic theoretical information on: the construction of the plant, the operation of the control panel, starting up and shutting down the plant, and doing everyday rounds and inspections. The training session for the second group, on the other hand, covered detailed theoretical information and the practical aspects of the subject matter, enabling the trainees to perform maintenance work, so called "small inspections", by themselves. In total, 14 persons were trained in both groups. The trained employees are able to operate the plant independently, while taking into account the guidelines provided in the GE Jenbacher documentation.

During last one year's operation of the GE JENBACHER JMS 316 GS-B.LC Engine Biogas Cogeneration Set the Ope-rator carried out all maintenance operations, as required in [10], on time. So far, maintenance has been completed after: the first start-up, 2000, 4000, 6000 and 8000 hrs of CHP set operation. The inspection after $2000 \mathrm{hrs}$ was carried out together with KWE Technika Energetyczna of BielskoBiala, the Authorized Representative of GE JENBACHER Gas Engines Division in Poland. The scope of all inspections carried out so far covered: checks and regulation of valve clearances, checks of the ignition system, the inspection of the gas path (biogas pressure regulation), the link mechanism and mixer regulation, the external table cooler, the electric generator, and venting of the gas engine's crankcase.

Since the commissioning of the generating set, the Operator has essentially encountered two significant problems. nicznej - Ogólne warunki - eksploatacja i konserwacja" [10], wyraźnie stwierdza, że przyrzeczone przez producenta właściwości produktu są gwarantowane tylko pod warunkiem przestrzegania warunków brzegowych dla silników gazowych GE JENBACHER, określonych w instrukcji TA nr 1100-0011 [10] i wykonywania wszystkich zalecanych działań wg książki eksploatacyjnej, której prowadzenie jest obligatoryjne. Wszystkie wymagane przez producenta prace serwisowe na instalacji biogazowego układu kogeneracyjnego z silnikiem GE JENBACHER JMS 212 GS-B.LC muszą być wykonywane terminowo i tylko przez odpowiednio przeszkolone osoby, a praca silnika powinna przebiegać bezstukowo. Przedziały czasowe prac serwisowych [10] stanowią wartości maksymalne, osiągane przy należycie prowadzonej eksploatacji i należycie wykonywanej konserwacji. Niedopuszczalne jest wydłużanie cykli serwisowych np. w celu uniknięcia postojów biogazowych zespołów kogeneracyjnych podczas sezonu grzewczego.

W grudniu 2008 r. serwis firmy KWE - Technika Energetyczna przeprowadził $\mathrm{w}$ dwóch grupach instruktaż dla pracowników OŚ WARTA. Grupa pierwsza składała się z dyspozytorów zmianowych, skład grupy drugiej tworzyły osoby przewidziane do wykonywania prac serwisowych. Instruktaż dla grupy pierwszej obejmował podstawowe informacje teoretyczne z zakresu: budowy urządzenia, obsługi panela sterowniczego, start i zatrzymanie urządzenia, codziennego obchodu i kontroli. Natomiast instruktaż dla grupy drugiej obejmował szczegółowe informacje teoretyczne oraz stronę praktyczną zagadnienia pozwalającą samodzielnie wykonywać prace serwisowe - „małe” przeglądy. Łącznie w obu grupach przeszkolono 14 osób. Przeszkoleni pracownicy są w stanie samodzielnie prowadzić eksploatację urządzenia mając na uwadze wytyczne zawarte w dokumentacji GE Jenbacher.

Podczas dotychczasowej - rocznej - eksploatacji biogazowego zespołu kogeneracyjnego z silnikiem GE JENBACHER JMS 316 GS-B.LC eksploatator wykonywał terminowo wszystkie wymagane w [10] czynności serwisowe. Dotychczas wykonano konserwację po: pierwszym uruchomieniu, 2000, 4000, 6000 i $8000 \mathrm{~h}$ pracy zespołu CHP. Przegląd po 2000 h pracy wykonany był wspólnie z firmą KWE - Technika Energetyczna Autoryzowany Przedstawiciel w Polsce GE JENBACHER Gas Engines Division z Bielsku-Białej. Zakres wszystkich dotychczasowych przeglądów obejmował: sprawdzenie i regulację luzów zaworowych, sprawdzenie instalacji zapłonowej, kontrolę: ścieżki gazowej (regulacji ciśnienia biogazu), mechanizmu dźwigniowego regulacji mieszalnika, zewnętrznej chłodnicy stołowej, generatora elektrycznego i odpowietrzenie skrzyni korbowej silnika gazowego.

Od chwili uruchomienia zespołu prądotwórczego eksploatator zetknął się zasadniczo z dwoma poważniejszymi problemami. Pierwszy wynikał z zakłóceń w zewnętrznej sieci elektrycznej (sygnalizacja asymetrii obciążeń faz). Problem drugi związany był bezpośrednio z uszkodzeniem regulatora $\cos \varphi$. Usterka ta była ciężką do zdiagnozowania, przeprowadzona kilkukrotnie przez serwis firmy KWE Technika Energetyczna zmiana nastaw regulatora nic nie 
The first of them was due to a disturbance in the external mains (signalization of phases load asymmetry). The second problem was directly associated with the failure of the $\cos \varphi$ governor. The failure was difficult to diagnose. Change of governor settings made several times by the KWE-Technika Energetyczna Service did not help; after changing the settings, the system behaved correctly for a few hours, after which the failure recurred. At last, a decision was made to replace the damaged governor, and the replacement was done by the KWE-Technika Energetyczna Service. Apart from the above-mentioned faults, the Biogas Cogeneration Set did not pose any technological and operational problems to the Operator.

The results of analysis of selected actual parameters of GE JENBACHER JMS 316 GS-B.LC Engine CHP Set operation with electric load similar to the rated load during the last operation - which has been made based on the annual records of those parameters reported in [9] - are summarized in Table 2.

The data concerning the last operation time of the GE JENBACHER JMS 316 GS-B.LC Engine Biogas Cogeneration Set, and the number of its start-ups and utilization rate are illustrated in Fig. 7 and 8.

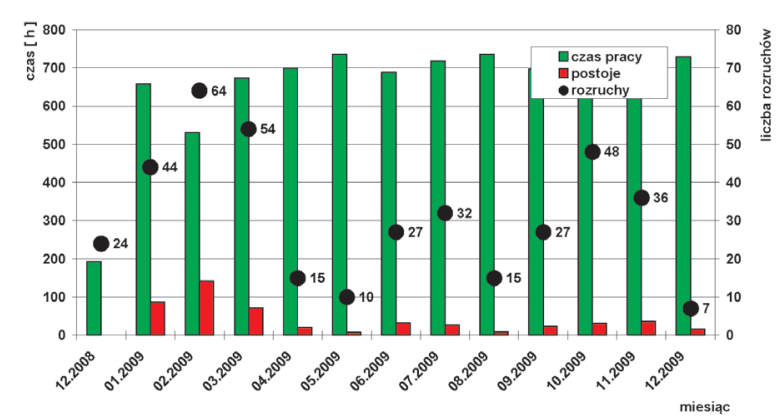

Fig. 7. The time of operation and shutdowns and the number of start-ups of the GE JENBACHER JMS 316 GS-B.LC Engine Biogas Cogeneration Set in the WARTA S.A. Waste Treatment Plant of Częstochowa

Rys. 7. Czas pracy i postojów oraz liczba rozruchów biogazowego zespotu kogeneracyjnego z silnikiem GE JENBACHER JMS 316 GS-B.LC w Oczyszczalni Ścieków WARTA S.A. w Częstochowie

In February 2009, a total of 142 hours of downtime of the Gas Cogeneration Set and an increased number (64) of its automatic shutdowns were noted due to disturbances in the external mains (signalization of phases load asymmetry). At the end of 2009, an uncontrolled increase in the number of automatic shutdowns (October - 48, November - 36) was noted again.

The data concerning the production of electrical energy and heat in the GE JENBACHER JMS 316 GS-B.LC Engine Biogas Cogeneration Set are represented in Fig. 9 through 11.

On the 5th of March, 2009, a billing system for electrical energy produced by the Biogas Cogeneration Set and used wholly for the Waste Treatment Plant's own purposes, using commercial electrical energy meters of the ZMD405CT manufactured by LANDIS+GYR DIALOG, and it has been pomogła, układ po przeregulowaniu zachowywał się kilka godzin poprawnie, po czym awaria się powtarzała. Zdecydowano się w końcu na wymianę uszkodzonego regulatora, wymiany dokonał serwis firmy KWE - Technika Energetyczna. Biogazowy zespół kogeneracyjny oprócz wspomnianych powyżej usterek nie sprawiał użytkownikowi żadnych problemów technologiczno - eksploatacyjnych. Wyniki analizy wybranych rzeczywistych parametrów pracy zespołu CHP z silnikiem GE JENBACHER JMS 316 GS-B.LC z obciążeniem elektrycznym zbliżonym do nominalnego podczas dotychczasowej eksploatacji-wykonanej w oparciu o roczne zapisy tych parametrów w [9] - zestawiono w tab. 2.

Dane dotyczące dotychczasowego czasu pracy biogazowego zespołu kogeneracyjnego z silnikiem GE JENBACHER JMS 316 GS-B.LC, liczby jego rozruchów oraz stopnia jego wykorzystania zilustrowano na rysunkach 7 i 8.

W lutym 2009 r. zanotowano łącznie 142 godziny postojów gazowego zespołu kogenracyjnego oraz zwiększoną liczbę jego automatycznych wyłączeń (64) z powodu zakłóceń w zewnętrznej sieci elektrycznej (sygnalizacja asymetri obciążeń faz). W końcu 2009 r. zanotowano ponownie, z podobnych przyczyn, niekontrolowany wzrost liczby automatycznych wyłączeń (październik - 48, listopad - 36)

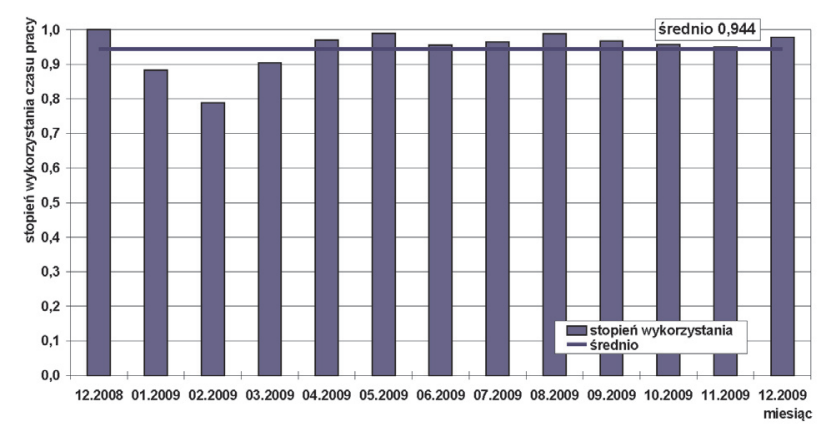

Fig. 8. The monthly operation time utilization rate of the GE JENBACHER JMS 316 GS-B.LC Engine Biogas Cogeneration Set in the WARTA S.A. Waste Treatment Plant of Częstochowa

Rys. 8. Miesięczny stopień wykorzystania czasu pracy biogazowego zespotu kogeneracyjnego z silnikiem GE JENBACHER JMS 316 GS-B.LC w Oczyszczalni Ścieków WARTA S.A. w Częstochowie

Dane dotyczące produkcji energii elektrycznej i ciepła w biogazowym zespole kogeneracyjnym z silnikiem GE JENBACHER JMS 316 GS-B.LC przedstawiono na rysunkach 9 do 11.

Od 05.03.2009 r. uruchomiono w OŚ WARTA S.A. system rozliczania energii elektrycznej wyprodukowanej $\mathrm{w}$ biogazowym zespole kogeneracyjnym i wykorzystywanej w całości na potrzeby własne oczyszczalni ścieków z wykorzystaniem przemysłowych liczników energii elektrycznej standardu ZMD405CT firmy LANDIS+GYR DIALOG. Specyfiką tego systemu rozliczeń jest to, iż wyprodukowana energia elektryczna nie jest sprzedawana odbiorcy zewnętrznemu po cenie niższej od tej, po której oczyszczalnia musiałaby taką energię zakupić do pokrycia potrzeb własnych - uniknięto m.in.: znaczących opłat za przesył energii elektrycznej. W układzie rozliczeń zainstalowane 
in use ever since. The specific feature of this billing system is that electrical energy produced is not sold to an external purchaser at a price lower than the price for which the Treatment Plant would have to purchase to cover its own needs; thus, considerable charges for the transmission of electrical energy have been avoided. In the billing system, also uni są także liczniki jednokierunkowe, których zadaniem jest rejestracja ewentualnej energii przekazywanej z oczyszczalni do zewnętrznej sieci elektrycznej i jej rozliczanie zgodnie z zawartą umową z ZE. Od marca 2009 r. wdrożono także w OŚ WARTA S.A. procedurę potwierdzania wyprodukowanej „energii zielonej” i uzyskiwania w Urzędzie Regulacji

Table 2. Selected actual parameters of operation of the GE JENBACHER JMS 316 GS-B.LC Engine CHP Set

Tabela 2. Wybrane rzeczywiste parametry pracy zespolu CHP z silnikiem GE JENBACHER JMS 316 GS-B.LC

\begin{tabular}{|c|c|c|}
\hline Specification/wyszczególnienie & $\begin{array}{c}\text { Unit/ } \\
\text { jednostka }\end{array}$ & $\begin{array}{l}\text { Range of variation/ } \\
\text { przedziat zmian }\end{array}$ \\
\hline Active power/moc czynna & $\mathrm{kW}$ & $827-830$ \\
\hline Engine biogas consumption/zużycie biogazu przez silnik & $\mathrm{m}^{3} / \mathrm{h}$ & $260-319$ \\
\hline Supercharging pressure/ciśnienie doładowania & bar & $2.20-2.88$ \\
\hline Throttle position/położenie przepustnicy & $\%$ & 100 \\
\hline Gas mixer position/pozycja mieszacza gazu & $\%$ & $20.4-22.8$ \\
\hline Turbocompressor bypass position/położenie obejściowe turbosprężarki & $\%$ & $20.1-36.9$ \\
\hline Cooling water temperature/temperatura wody chłodzacej & ${ }^{\circ} \mathrm{C}$ & $79.6-90.9$ \\
\hline Cooling water pressure/ciśnienie wody chłodzacej & bar & $1.03-1.65$ \\
\hline Oil temperature/temperatura oleju & ${ }^{\circ} \mathrm{C}$ & $66.0-89.0$ \\
\hline Oil pressure/ciśnienie oleju & bar & $3.91-4.32$ \\
\hline Cooled mixture temperature/temperatura schłodzonej mieszanki & ${ }^{\circ} \mathrm{C}$ & $41.8-61.1$ \\
\hline Exhaust gas temperature after cylinder 1 /temperatura spalin za cylindrem 1 & ${ }^{\circ} \mathrm{C}$ & $523-556$ \\
\hline Exhaust gas temperature after cylinder 2/temperatura spalin za cylindrem 2 & ${ }^{\circ} \mathrm{C}$ & $525-583$ \\
\hline Exhaust gas temperature after cylinder 3/temperatura spalin za cylindrem 3 & ${ }^{\circ} \mathrm{C}$ & $532-566$ \\
\hline Exhaust gas temperature after cylinder 4/temperatura spalin za cylindrem 4 & ${ }^{\circ} \mathrm{C}$ & $523-565$ \\
\hline Exhaust gas temperature after cylinder 5/temperatura spalin za cylindrem 5 & ${ }^{\circ} \mathrm{C}$ & $534-567$ \\
\hline Exhaust gas temperature after cylinder 6/temperatura spalin za cylindrem 6 & ${ }^{\circ} \mathrm{C}$ & $523-563$ \\
\hline Exhaust gas temperature after cylinder 7/temperatura spalin za cylindrem 7 & ${ }^{\circ} \mathrm{C}$ & $530-590$ \\
\hline Exhaust gas temperature after cylinder $8 /$ temperatura spalin za cylindrem 8 & ${ }^{\circ} \mathrm{C}$ & $531-571$ \\
\hline Exhaust gas temperature after cylinder 9/temperatura spalin za cylindrem 9 & ${ }^{\circ} \mathrm{C}$ & $532-560$ \\
\hline Exhaust gas temperature after cylinder 10/temperatura spalin za cylindrem 10 & ${ }^{\circ} \mathrm{C}$ & $525-567$ \\
\hline Exhaust gas temperature after cylinder 11/temperatura spalin za cylindrem 11 & ${ }^{\circ} \mathrm{C}$ & $533-563$ \\
\hline Exhaust gas temperature after cylinder 12/temperatura spalin za cylindrem 12 & ${ }^{\circ} \mathrm{C}$ & $526-556$ \\
\hline Exhaust gas temperature after cylinder 13/temperatura spalin za cylindrem 13 & ${ }^{\circ} \mathrm{C}$ & $530-560$ \\
\hline Exhaust gas temperature after cylinder 14/temperatura spalin za cylindrem 14 & ${ }^{\circ} \mathrm{C}$ & $531-562$ \\
\hline Exhaust gas temperature after cylinder 15/temperatura spalin za cylindrem 15 & ${ }^{\circ} \mathrm{C}$ & $532-561$ \\
\hline Exhaust gas temperature after cylinder 16/temperatura spalin za cylindrem 16 & ${ }^{\circ} \mathrm{C}$ & $536-591$ \\
\hline $\begin{array}{l}\text { Exhaust gas temperature before the exhaust gas-water heat exchange/temperatura spalin przed wymiennikiem } \\
\text { ciepła spaliny-woda }\end{array}$ & ${ }^{\circ} \mathrm{C}$ & $450-520$ \\
\hline $\begin{array}{l}\text { Exhaust gas temperature after the exhaust gas-water heat exchanger/temperatura spalin za wymiennikiem ciepła } \\
\text { spaliny-woda }\end{array}$ & ${ }^{\circ} \mathrm{C}$ & $216-294$ \\
\hline $\begin{array}{l}\text { Warm process water temperature after the exhaust gas-water heat exchanger/temperatura cieplej wody technolo- } \\
\text { gicznej za wymiennikiem spaliany-woda }\end{array}$ & ${ }^{\circ} \mathrm{C}$ & $64-96$ \\
\hline Machine room air temperature/temperatura powietrza $w$ maszynowni & ${ }^{\circ} \mathrm{C}$ & $15-37$ \\
\hline Outdoor air temperature/temperatura powietrza na zewnatrz & ${ }^{\circ} \mathrm{C}$ & $-17-35$ \\
\hline $\cos \varphi$ & - & $0.8-1.0$ \\
\hline Mean current/średni prąd & A & $65-98$ \\
\hline Mean voltage/średnie napięcie & $\mathrm{V}$ & $6090-6294$ \\
\hline Field voltage/napięcie wzbudzenia & $\mathrm{V}$ & $18.2-35.3$ \\
\hline $\begin{array}{l}\text { Temperature of generator bearings on the Gas Engine side/temperatura łożysk generatora od strony silnika } \\
\text { gazowego }\end{array}$ & ${ }^{\circ} \mathrm{C}$ & $26.2-63.8$ \\
\hline Temperature of generator bearings on the free side/temperatura tożysk generatora od wolnej strony & ${ }^{\circ} \mathrm{C}$ & $23.3-66.7$ \\
\hline
\end{tabular}




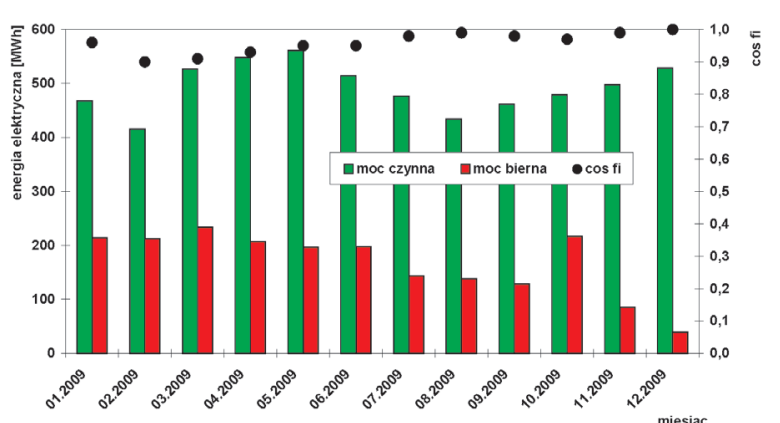

Fig. 9. Electrical energy generated by the GE JENBACHER JMS 316 GS-B.LC Engine Biogas Cogeneration Set in the WARTA S.A. Waste Treatment Plant of Częstochowa

Rys. 9. Energia elektryczna wyprodukowana przez biogazowy zespót kogeneracyjny z silnikiem GE JENBACHER JMS 316 GS-B.LC w Oczyszczalni Ścieków WARTA S.A. w Częstochowie

directional meters are installed, whose purpose is to record any possible energy transferred from the Treatment Plant to the external power network and to account for it according to the contract concluded with the ZE (Electricity Board). In March 2009, a procedure was also implemented in the WARTA S.A. Waste Treatment Plant for the confirmation of "green energy" produced and the obtaining of "Certificates of Origin" from the Energy Regulation Authority for energy produced in the OZE, which can be advantageously sold by The Treatment Plant at the Commodity Energy Exchange $[15,17]$ to enterprises which, in the framework of the Property Rights Market that has been active in Poland since December, 2005, have to fulfil the duty imposed on them under the "Energy Law" to obtain "Certificates of Origin" from cogeneration and submit them to the President of the URE to be remitted.

In the period from 5.03.2009 to 31.12.2009, the WARTA S.A. Waste Treatment Plant of Częstochowa obtained 10 Certificates of Origin for a total amount of 4943.41 MWh generated electrical energy, which made up $100 \%$ of electrical energy produced in that period. The number of any possible Certificates of Origin sold and the profit gained are confidential information and constitute the Company's business secret.

The first Certificate Origin from cogeneration obtained by the WARTA S.A. Waste Treatment Plant of Częstochowa is presented in Fig. 12.

The data for the electrical energy balance of the WARTA S.A. Waste Treatment Plant of Częstochowa are illustrated in Fig. 13. The slight differences in the amount of energy produced and allocated for internal purposes (March, 2009) resulted from the errors in its conversions on untypical current transformers during starting up the electrical energy measuring and billing system and from the fact that this system was only started up on March the 5th, 2009. The WARTA S.A. Waste Treatment Plant of Częstochowa orders electrical energy at a level of $1.5 \mathrm{MW}$ from two independent sources, and, in addition, a so called safety power of $0.4 \mathrm{MW}$ from a third source (in the event of a possible evacuation of the personnel and shutting down the technology).

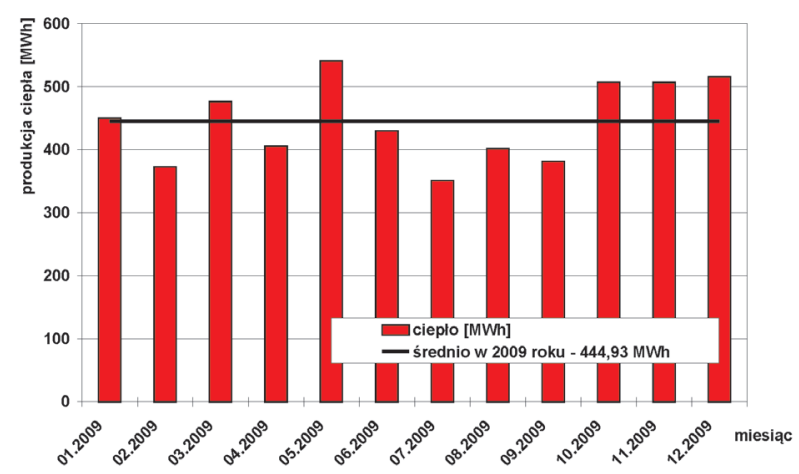

Fig. 10. Heat energy generated by the GE JENBACHER JMS 316 GS-B.LC Engine Biogas Cogeneration Set in the WARTA S.A. Waste Treatment Plant of Częstochowa

Rys. 10. Ciepło wyprodukowane przez biogazowy zespoł kogeneracyjny z silnikiem GE JENBACHER JMS 316 GS-B.LC w Oczyszczalni Ścieków WARTA S.A. w Częstochowie

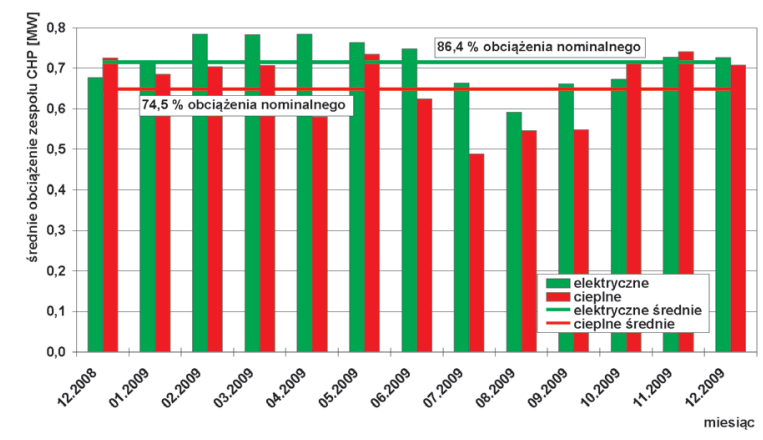

Fig. 11. The average hourly electric and thermal load of the GE JENBACHER JMS 316 GS-B.LC Engine Biogas Cogeneration Set in the WARTA S.A. Waste Treatment Plant of Częstochowa

Rys. 11. Średnie godzinowe obciażenie elektryczne i cieplne biogazowego zespolu kogeneracyjnego z silnikiem GE JENBACHER JMS 316 GS-B. LC w Oczyszczalni Ścieków WARTA S.A. w Częstochowie

Energetyki „Świadectw pochodzenia” za energię elektryczną wyprodukowaną w OZE, które mogą być korzystnie sprzedawane przez oczyszczalnię na Towarowej Giełdzie Energii $[15,17]$ w ramach działającego w Polsce od grudnia 2005 r. Rynku Praw Majątkowych [15], przedsiębiorstwom, które muszą wypełnić narzucony im „Prawem energetycznym” obowiązek uzyskania i przedstawienia do umorzenia Prezesowi URE „Świadectw pochodzenia” z kogeneracji.

OŚ WARTAS.A. w okresie od 5.03.2009 r. do 31.12.2009 r. uzyskała 10 świadectw pochodzenia, na łączną sumę 4943,41 MWh wytworzonej ilości energii elektrycznej, co stanowiło $100 \%$ energii elektrycznej wyprodukowanej w tym okresie. Liczba ewentualnych odsprzedanych świadectw pochodzenia oraz zysk są informacjami poufnymi i stanowią tajemnicę handlową firmy.

Pierwsze świadectwo pochodzenia z kogeneracji, uzyskane przez OŚ WARTA S.A., zaprezentowano na rys. 12.

Dane dotyczące bilansu energii elektrycznej OŚ WARTA S.A. zobrazowano na rys. 13. Niewielkie różnice w ilości energii wyprodukowanej i oddanej na potrzeby własne (03.2009 r.) wynikały z błędów jej przeliczeń na nietypowych przekładnikach prądowych podczas uruchamiania 


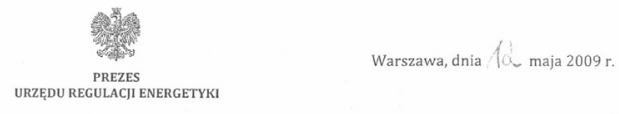

\section{ŚWIADECTWO POCHODZENIA}

Nr PL0024554/BGO/01/13983/2009

Zaświadcza się, że niżej wymieniona ilość energii elektrycznej została wytworzona w odnawialnym źródle energii.

Rodzaj źródła: elektrownia biogazowa

Moc zainstalowana: 0,830 MW

Lokalizacja źródła: Czesstochowa

Wytwórca: Oczyszczalnia Ścieków WARTA S.A., ul. Srebrna 172/188, 42-201 Częstochowa

Okres wytworzenia energii: 5 marca 2009 r. - 31 marca 2009 r. Ilość energii elektrycznej objęta świadectwem: 451,791 MWh

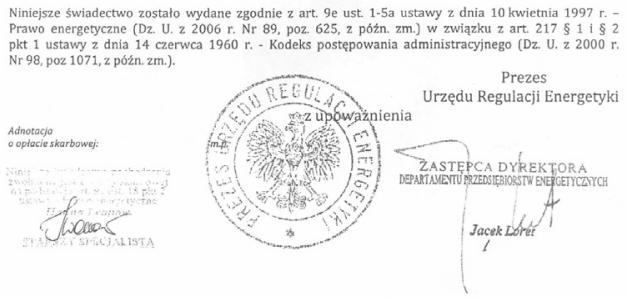

Fig. 12. The first Certificate of Origin from cogeneration confirming the production of electrical energy in a renewable energy source, obtained by the WARTA S.A. Waste Treatment Plant of Częstochowa

Rys. 12. Pierwsze świadectwo pochodzenia z kogeneracji potwierdzajace wyprodukowanie energii elektrycznej $w$ odnawialnym źródle energii uzyskane przez Oczyszczalnię Ścieków WARTA S.A. w Częstochowie

In the period under analysis, the WARTA S.A. Waste Treatment Plant covered in average 53\% (a maximum of $63 \%$ in May, and a minimum of $46.3 \%$ in February, 2009) of its energy demands with its own electrical energy production.

The degree of coverage of the WARTA S.A. Waste Treatment Plant's demand for electrical energy and heat in 2009 with its own production in the GE JENBACHER JMS 316 GS-B.LC Engine Biogas Cogeneration Set is illustrated in Fig. 14.

The heat needed for the uninterrupted operation of the WARTA S.A. Waste Treatment Plant in Częstochowa can be acquired from three sources, i.e.: the Boiler Room, the Drier, and the Biogas Cogeneration Set. The WARTA S.A. Waste Treatment Plant's heat balance indicates that the annual heat demand is estimated at a level of 43,470 GJ. The amount of heat recovered in the Biogas Cogeneration Set in the period under consideration allowed the WARTA S.A. Waste Treatment Plant's heat demand to be covered in an average degree of $44 \%$. In the summer season (16.04-15.10), a 45\% surplus of Cogeneration Set produced heat as against the Treatment Plant's demand occurred, and this was wholly dissipated on the fan cooler mounted on the Thermal-Electric Power Station building. In the winter season (16.10-15.04) the heat produced in the Biogas Cogeneration Set was utilized in full.

The biogas balance of WARTA S.A. Waste Treatment Plant in Częstochowa is shown in Figs 15 and 16, while the systemu pomiaru i rozliczania energii elektrycznej oraz $\mathrm{z}$ faktu uruchomienia tego systemu dopiero od 05.03.2009 r. OŚ WARTA S.A. zamawia z dwóch niezależnych źródeł moc elektryczną na poziomie $1,5 \mathrm{MW}$ i dodatkowo z trzeciego źródła 0,4 MW tzW. mocy bezpieczeństwa (na wypadek konieczności ewentualnej ewakuacji załogi i wyłączenia technologii).

OŚ WARTA S.A pokrywała w analizowanym okresie własną produkcją energii elektrycznej średnio ok. 53\% (maks. w maju 2009 r. - 63\%, zaś min. w lutym - 46,3\%) swojego zapotrzebowania w tym zakresie.

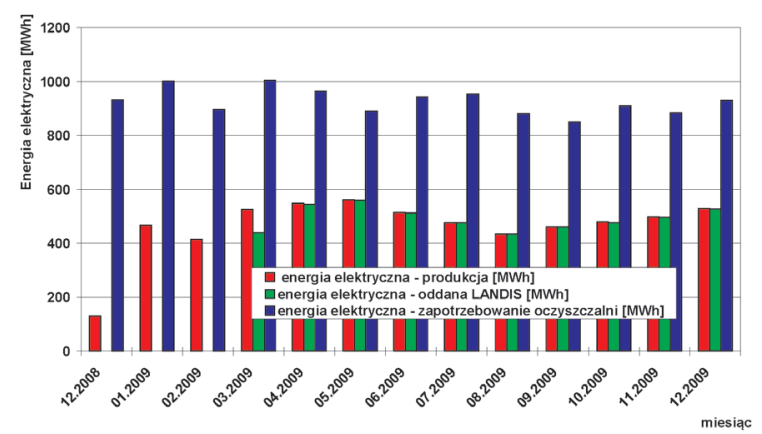

Fig. 13. Electrical energy balance of the WARTA S.A. Waste Treatment Plant of Częstochowa

Rys. 13. Bilans energii elektrycznej Oczyszczalni Ścieków WARTA S.A. w Częstochowie

Stopień pokrycia zapotrzebowania OŚ WARTA S.A. w 2009 roku na energię elektryczną i ciepło produkcją własną w biogazowym zespole kogeneracyjnym z silnikiem GE JENBACHER JMS 316 GS-B.LC zobrazowano na rys. 14.

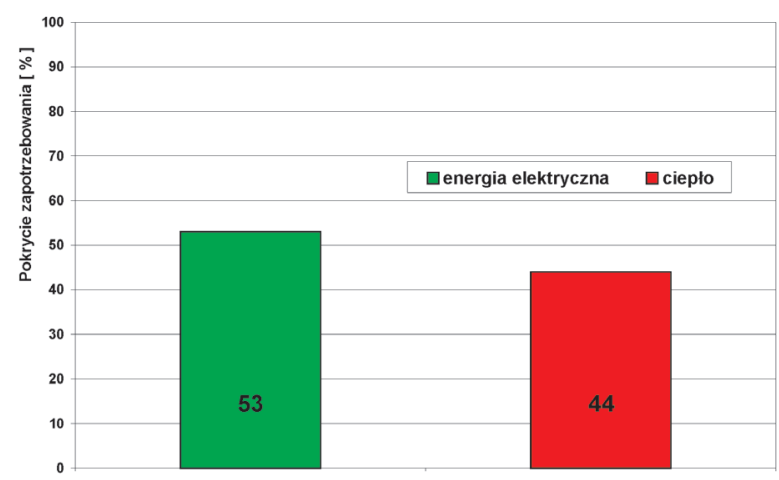

Fig. 14. The degree of coverage of the WARTA S.A. Waste Treatment Plant's demand for electrical energy and heat in 2009 with its own production in the GE JENBACHER JMS 316 GS-B.LC Engine Biogas Cogeneration Set

Rys. 14. Stopień pokrycia zapotrzebowania Oczyszczalni Ścieków WARTA S.A. w 2009 r. na energię elektryczna i ciepło produkcja własna w biogazowym zespole kogeneracyjnym z silnikiem GE JENBACHER JMS 316 GS-B.LC

Ciepło potrzebne dla niezakłóconej pracy OŚ WARTA S.A. może być pozyskiwane z trzech źródeł tj.: kotłowni, suszarni oraz biogazowego zespołu kogeneracyjnego. Z bilansu cieplnego OŚ WARTA S.A. wynika, że roczne zapotrzebowanie na ciepło kształtuje się na poziomie 43470 GJ. Ilość 
unit biogas consumption by the GE JENBACHER JMS 316 GS-B.LC Engine Cogeneration Set - in Fig. 17.

The biogas consumption in the flare stack occurs incidentally, most often during planned shutdowns of the Cogeneration Set. The amount of biogas combusted there is not subject to measurement and is the difference between its production and consumption by the Biogas Cogeneration Set and the Boiler Room.

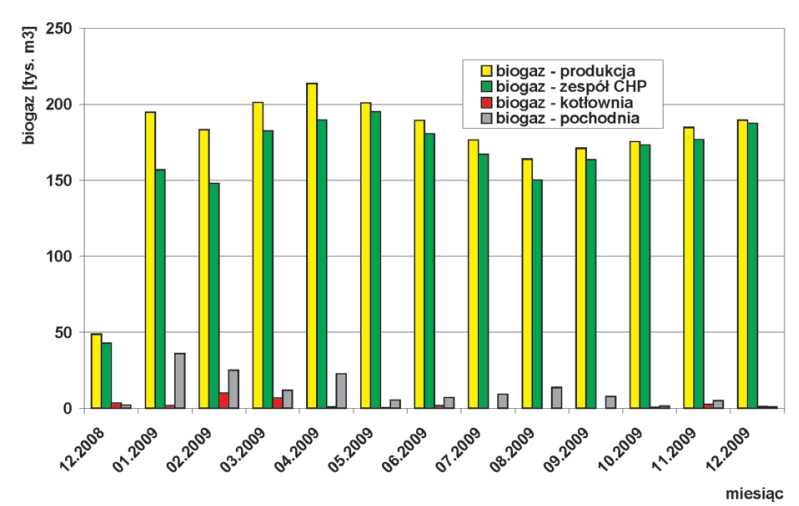

Fig. 15. The biogas balance of the WARTA S.A. Waste Treatment Plant of Częstochowa on a monthly basis

Rys. 15. Bilans biogazu Oczyszczalni Ścieków WARTA S.A. w Częstochowie w uktadzie miesięcznym

The GE JENBACHER JMS 316 GS-B.LC Biogas Engine is operated on MOBIL PEGASUS 610 SAE 40 class oil and equipped with a system of automatic oil level monitoring and topping up. The high level of sulphate ash (1 wt.\%) in this oil causes the absorption of halides and hydrogen sulphide that may occur in biogas and helps to keep the combustion ciepła odzyskanego w biogazowym zespole kogeneracyjnym w rozpatrywanym okresie pozwoliła na średnie pokrycie 44\% zapotrzebowania OŚ WARTA S.A. w tym zakresie. W okresie letnim (16.04-15.10) wystąpiła 45\% nadwyżka wyprodukowanego ciepła w zespole w stosunku do zapotrzebowania oczyszczalni i zostało ono w całości rozproszone w chłodnicy wentylatorowej posadowionej na dachu budynku elektrociepłowni. W okresie zimowym (16.10-15.04) ciepło wyprodukowane w biogazowym zespole kogeneracyjnym zostało w całości wykorzytsane. Bilans biogazu OŚ WARTA S.A. pokazano na rys. 15 i 16, zaś jednostkowe zużycie biogazu przez zespół kogeneracyjny z silnikiem GE JENBACHER JMS 316 GS-B.LC - na rys. 17.

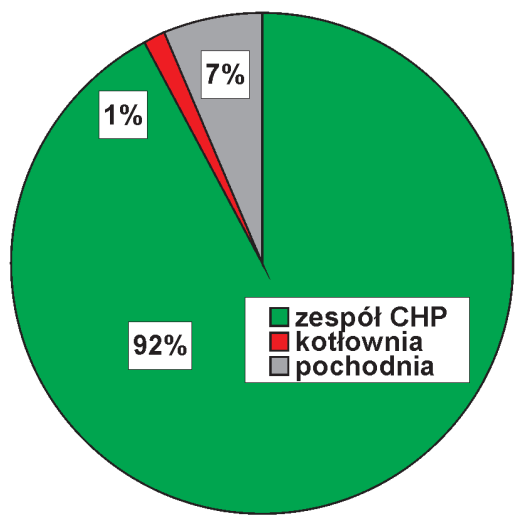

Fig. 16. The biogas balance of the WARTA S.A. Waste Treatment Plant of Częstochowa in the last period of operation of the GE JENBACHER JMS 316 GS-B.LC Engine Biogas Cogeneration Set

Rys. 16. Bilans biogazu Oczyszczalni Ścieków WARTA S.A. w Częstochowie w okresie dotychczasowej eksploatacji biogazowego zespołu kogeneracyjnego z silnikiem GE JENBACHER JMS 316 GS-B.LC

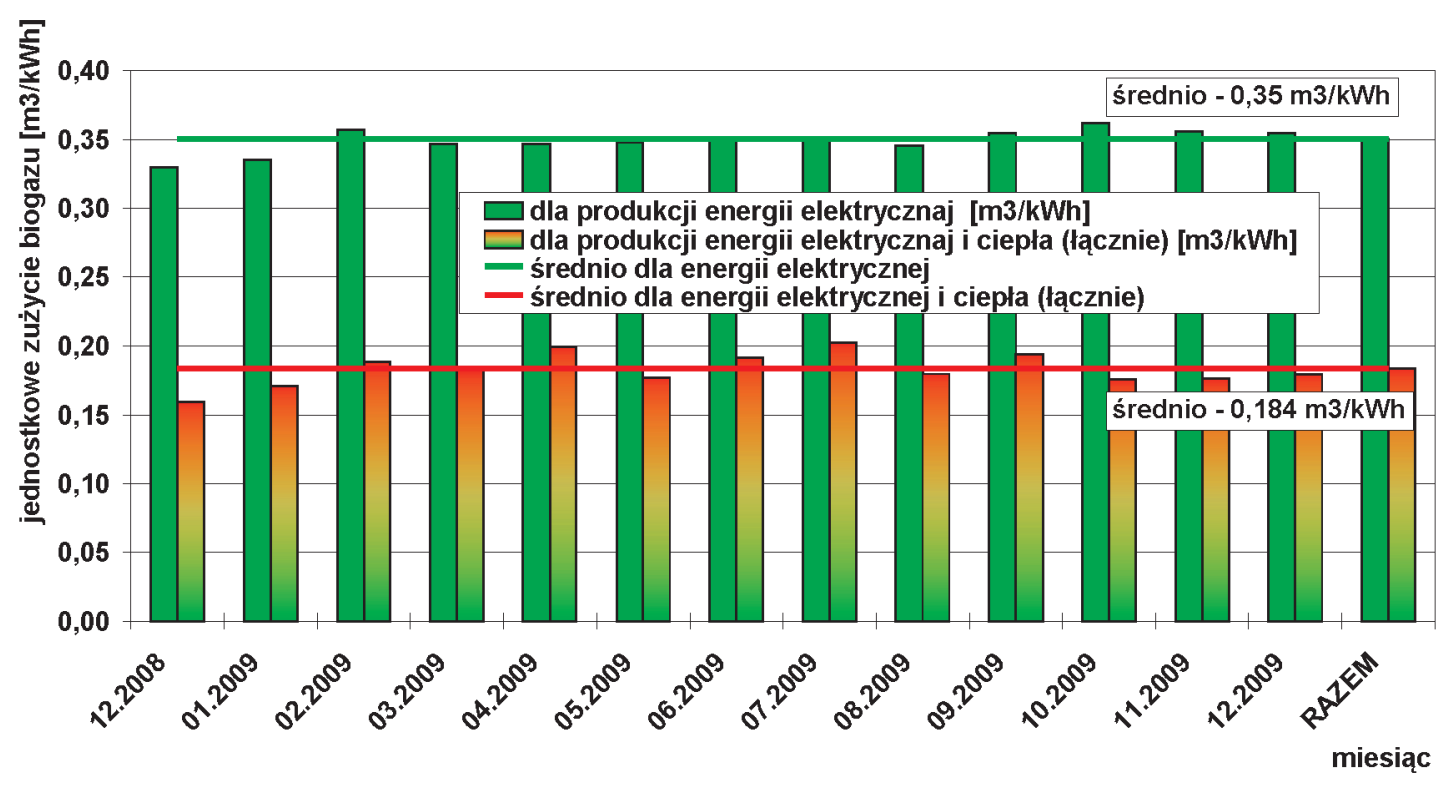

Fig. 17. Unit biogas consumption by the GE JENBACHER JMS 316 GS-B.LC Engine Biogas Cogeneration Set in the WARTA S.A. Waste Treatment Plant of Częstochowa

Rys. 17. Jednostkowe zużycie biogazu w zespole kogeneracyjnym z silnikiem GE JENBACHER JMS 316 GS-B.LC w Oczyszczalni Ścieków WARTA S.A. w Częstochowie 
chamber clean and protects the valves against the action of the aggressive biogas. The better stability and oxidation resistance of the PEGASUS 610 oil is owing to high-paraffined base oils used. It contains also anti-wear additives and washing agents (detergents) and dispersing agents.

The Biogas Engine Manufacturer has not specified the maintenance period for lubricating oil. Undertaking any activities, as necessary for the protection and operational safety of the CHP installation and its availability is the responsibility of the Operator [10]. Therefore, in conformance with the GE JENBACHER recommendations [10], the Operator regularly (every $500 \mathrm{hrs}$ of engine operation) takes samples and outsources the testing of their quality to a certified laboratory, which is the Signum Laboratory of EXXON MOBIL, as recommended by the Manufacturer.

During the last operation covering 8450 hours of engine running (as per 31.12.2009), the lubricating oil was exchanged four times ( $300 \mathrm{dm}^{3}$ each time):

- 12.03.2009 - after running $1603 \mathrm{hrs}$ by the engine,

- 22.05.2009 - after running $3274 \mathrm{hrs}$ by the engine (1671 hrs since the oil exchange),

- 05.08.2009 - after running $5010 \mathrm{hrs}$ by the engine (1736 hrs since the oil exchange), and

- 29.10.2009 - after running 6992 hrs by the engine (1982 hrs since the oil exchange),

which gives the average time between oil exchanges at a level of $1748 \mathrm{hrs}$.

According to information obtained the Operator, the actual unit consumption of lubricating oil by the GE JENBACHER JMS 316 GS-B.LC Engine (resulting from the difference between the amounts of lubricating oil purchased and used during the year) is estimated at a level of approx. $0.2 \mathrm{~g} / \mathrm{kWh}$, thus being lower than the figure declared by the Supplier in his offer, which is $0.3 \mathrm{~g} / \mathrm{kWh}$ (until the first major repair). The GE JENBACHER JMS 316 GS-B.LC Biogas Engine is operated on two JENBACHER P7.1V6 sparking plugs (Fig. 18).

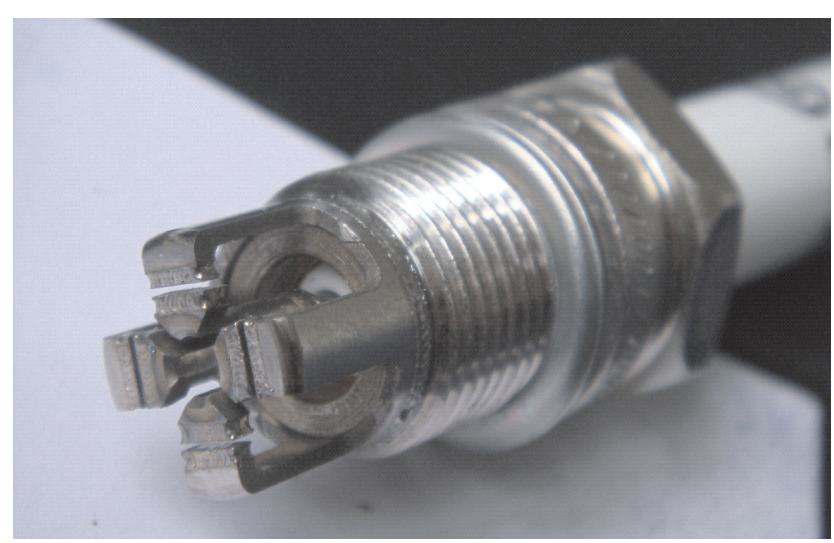

Fig. 18. The GE JENBACHER P7.1V6 sparking plug used in the GE JENBACHER JMS 316 GS-B.LC Biogas Engine

Rys. 18. Świeca zaplonowa GE JENBACHER P7.1V6 stosowana w silniku biogazowym GE JENBACHER JMS 316 GS-B.LC

The Manufacturer of the GE JENBACHER JMS 316 GS-B.LC Biogas Engine has not specified the life of the
Zużycie biogazu w pochodni występuje incydentalnie, najczęściej podczas planowanych postojów zespołu kogeneracyjnego. Ilość spalonego tam biogazu nie jest opomiarowana i jest różnicą pomiędzy jego produkcją i zużyciem przez biogazowy zespół kogeneracyjny i kotłownię.

Silnik biogazowy GE JENBACHER JMS 316 GS-B.LC eksploatowany jest na oleju klasy SAE 40 MOBIL PEGASUS 610 i jest wyposażony w układ automatycznej kontroli jego poziomu i uzupełniania [13]. Wysoki poziom popiołu siarczanowego (1\% wagowo) [18] w tym oleju powoduje absorpcję halogenków i siarkowodoru mogących w występować w biogazie oraz pomaga utrzymać w czystości komorę spalania oraz chroni zawory przed wpływem agresywnego biogazu. Lepsza stabilność i odporność na utlenianie oleju PEGASUS 610 jest wynikiem zastosowania wysoko rafinowanych parafinowych olejów bazowych. Zawiera on także dodatki przeciwzużyciowe oraz dodatki myjące (detergenty) i dyspergujące.

Producent silnika biogazowego nie ustalił cyklu konserwacyjnego dla oleju smarującego. Za podejmowanie wszelkich działań niezbędnych dla ochrony i bezpieczeństwa eksploatacyjnego instalacji CHP i jej dyspozycyjności odpowiada jej eksploatator [10]. W związku z powyższym eksploatator regularnie pobiera zgodnie z zaleceniami GE JENBACHER [10] próbki oleju smarującego (co $500 \mathrm{~h}$ pracy silnika) i zleca badanie ich jakości w certyfikowanym laboratorium firmy EXXON MOBIL - Signum Laboratory przez niego rekomendowanym.

Podczas dotychczasowej eksploatacji obejmującej 8450 h (stan 31.12.2009 r.) pracy silnika, olej smarujący (w ilości po $300 \mathrm{dm}^{3}$ ) wymieniono czterokrotnie:

- 12.03.2009 r. - po przepracowaniu przez silnik $1603 \mathrm{~h}$,

- 22.05.2009 r. - po przepracowaniu przez silnik $3274 \mathrm{~h}$ (1671 h od wymiany oleju),

- 05.08.2009 r. - po przepracowaniu przez silnik $5010 \mathrm{~h}$ (1736 h od wymiany oleju),

- 29.10.2009 r. - po przepracowaniu przez silnik 6992 h (1982 h od wymiany oleju),

co daje średni czas między wymianami oleju na poziomie $1748 \mathrm{~h}$.

Wg informacji uzyskanych od eksploatatora, rzeczywiste jednostkowe zużycie oleju smarującego przez silnik GE JENBACHER JMS 316 GS-B.LC (wynikające z różnicy zakupu i zużycia oleju smarującego w ciągu roku) kształtuje się dotychczas na poziomie ok. $0,2 \mathrm{~g} / \mathrm{kWh}$ i jest niższe od zadeklarowanego w przez dostawcę w ofercie - 0,3 g/kWh (do pierwszej naprawy głównej). Silnik biogazowy GE JENBACHER JMS 316 GS-B.LC eksploatowany jest na świecach zapłonowych JENBACHER P7.1V6 (rys. 18).

Producent silnika biogazowego GE JENBACHER JMS 316 GS-B.LC nie określił trwałości świec zapłonowych. Za podejmowanie wszelkich działań niezbędnych dla ochrony i bezpieczeństwa eksploatacyjnego instalacji CHP i jej dyspozycyjności odpowiada jej eksploatator [10]. Okres między kolejnymi wymianami świec zapłonowych zależy od warunków brzegowych specyficznych dla danej instalacji CHP, a głównie od typu świec zapłonowych, jakości bio- 
sparking plugs. Undertaking any activities, as necessary for the protection and operational safety of the CHP installation and its availability is the responsibility of the Operator [10]. The period between successive replacements of the sparking plugs depends on the boundary conditions being specific to a particular CHP installation, and mainly on the sparking plug type, biogas quality, average pressure, gas mixture temperature, the ignition system type, and the limiting values of emission. The Biogas Engine's Manufacturer recommends regular checks of the sparking discharge voltage on individual sparking plugs to be carried out using a FLUKE 123 commercial scopemeter and, should the permissible value of $32 \mathrm{kV}$ [8] be exceeded, their cleaning and adjustment, or replacement with new ones. The Operator performs regular checks (once a week) of sparking discharge voltage on individual sparking plugs. The obtained results are recorded. The Operator make efforts to ensure that sparking discharge voltages on individual sparking plugs do not exceed $25 \mathrm{kV}$. If the measured voltages are higher, a periodic replacement of the whole set (16 units) of sparking plugs is made, as the Operator has two sparking plug sets available. This approach is very practical in operational terms, as it shortens the shutdowns of the Biogas Cogeneration Set to a minimum necessary only for the replacement of sparking plugs. The time interval between successive replacements of sparking plugs (up to their cleaning and adjustment) does not exceeds 21 days.

The value of the electrode gap, as recommended by the Manufacturer for these sparking plugs, is $0.35 \mathrm{~mm}$ [10]. The manufacturer of the sparking plugs estimates their life at about 15,000 hours of operation. The option of reducing the sparking discharge energy to operate the engine at its lower levels, which is available in the ignition system, allows an extension of the life of the relatively expensive sparking plugs, whose unit price is going for about 1.5 thousand zlotys [6].

\section{Conclusions}

- As early as in the seventies of the $20^{\text {th }}$ century, the WARTA S.A. Waste Treatment Plant, jointly with the IMTiTS PCz, initiated Poland's first work on the utilization of biogas being a by-product of anaerobic sewage sludge fermentation, by using it for supplying cogeneration sets coupled with piston engines to co-generate electric energy and heat.

- The new Cogeneration Set with the GE JENBACHER JMS 316 GS-B.LC Engine was commissioned at the WARTA S.A. Waste Treatment Plant in Częstochowa on the $24^{\text {th }}$ of December, 2008. The investment project, with a cost of 3.7 million zlotys, was completed in a very short time of seven months.

- The operation of the GE JENBACHER JMS 316 GS-B. LC Engine Cogeneration Set so far has not posed any technical difficulties; the set operates trouble-free, and its technical condition is good.

- Following the Manufacturer's recommendations and schedule, the Operator carries out the required periodic maintenance activities by outsourcing them to the CHP Supplier - KWE Technika Energetyczna Sp. z o.o., the gazu, średniego ciśnienia, temperatury mieszanki gazowej, rodzaju instalacji zapłonowej, wartości granicznych emisji. Producent silnika biogazowego zaleca regularną kontrolę napięcia wyładowania iskrowego na poszczególnych świecach zapłonowych z wykorzystaniem skopometru przemysłowego FLUKE 123 i w razie przekroczenia wartości dopuszczalnej - $32 \mathrm{kV}$ [8] - ich czyszczenie i regulację, ewentualnie ich wymianę na nowe. Eksploatator wykonuje regularną kontrolę (raz w tygodniu) napięcia wyładowania iskrowego na poszczególnych świecach zapłonowych. Uzyskane wyniki są ewidencjonowane. Eksploatator stara się, aby napięcia wyładowania iskrowego na poszczególnych świecach nie przekraczały wartości $25 \mathrm{kV}$. Jeżeli pomierzone napięcia są wyższe, następuje okresowa wymiana całego kompletu (16 szt.) świec zapłonowych, gdyż eksploatator posiada dwa komplety świec zapłonowych. Jest to bardzo praktyczne rozwiązanie pod względem eksploatacyjnym, ponieważ znacząco skraca to postoje biogazowego zespołu kogeneracyjnego do minimum niezbędnego jedynie do ponownej wymiany świec zapłonowych. Okres między wymianami świec zapłonowych (do ich czyszczenia i regulacji) nie przekracza 21 dni. Wartość odstępu międzyelektrodowego zalecana przez producenta dla tych świec zapłonowych wynosi 0,35 mm [10]. Producent świec zapłonowych szacuje ich żywotność na ok. 15000 godzin pracy. Dostępna w układzie zapłonowym opcja zmniejszenia energii wyładowania iskrowego i pracy silnika przy mniejszych jej wartościach, umożliwia zwiększenie żywotności stosunkowo drogich świec zapłonowych, których cena jednostkowa kształtuje się w okolicach 1,5 tys. zł [6].

\section{Podsumowanie}

- Oczyszczalnia Ścieków WARTA S.A. w Częstochowie wraz z IMTiTS PCz zapoczątkowała już w latach siedemdziesiątych XX. wieku krajowe prace dotyczące utylizacji biogazu będącego ubocznym produktem beztlenowej fermentacji osadów poprzez wykorzystanie go do zasilania zespołów kogeneracyjnych z silnikami tłokowymi produkujących w skojarzeniu energię elektryczną i ciepło.

- Nowy biogazowy zespół kogeneracyjny z silnikiem GE JENBACHER JMS 316 GS-B.LC uruchomiono w OŚ WARTA S.A. 24.12.2008 roku. Inwestycja o koszcie 3,7 mln zl, została zrealizowana w bardzo krótkim okresie czasu - siedmiu miesięcy.

- Dotychczasowa eksploatacja biogazowego zespołu kogeneracyjnego z silnikiem GE JENBACHER JMS 316 GS-B. LC nie stwarza trudności technicznych, zespół pracuje bezawaryjnie a jego stan techniczny jest dobry.

- Eksploatator zgodnie z zaleceniami producenta i harmonogramem przeprowadza wymagane okresowe konserwacje zlecając je serwisowi dostawcy zespołu CHP - firmie KWE Technika Energetyczna Sp. z o.o. Autoryzowany Przedstawiciel w Polsce GE JENBACHER Gas Engines Division z Bielska-Białej.

- Gazowy zespół CHP eksploatowany jest od chwili jego uruchomienia bardzo intensywnie, osiągając wysoki średni wskaźnik wykorzystania miesięcznego czasu 
Authorized Representative of GE JENBACHER for Poland.

- The CHP Gas Set has been operated very intensively since the time of its commissioning, attaining a very high average monthly operation time utilization rate of $94.4 \%$, except for the month of February, when a 142-hour shutdown was noted, along with 64 hours of its restarting due to disturbances in the external power network.

- The Cogeneration Set had worked for 8450 hours by the Dec. the 31st, 2009, producing during this time 6042.7 MWh of electrical energy and 19,722.30 GJ (5478,42 MWh) of heat, while the coverage of the Treatment Plant's demands for electrical energy and heat by its own production was $53 \%$ and $44 \%$, respectively.

- The average monthly load of the Cogeneration Set during the last operation was $0.715 \mathrm{MW}$, which accounted for 86.4 $\%$ of its rated load, while the average thermal load was, respectively, $0.648 \mathrm{MW}$, and $74.5 \%$ of its rated load.

- The average biogas output of the WARTA S.A. Waste Treatment Plant in the period under analysis was at a level of $271.7 \mathrm{~m}^{3} / \mathrm{h}$, while the rate of biogas consumption by the Cogeneration Set was $250.5 \mathrm{~m}^{3} / \mathrm{h}$.

- The average unit biogas consumption in the operation period under examination amounted to $0.350 \mathrm{~m}^{3} / \mathrm{kWh}$ of electrical energy and $0.184 \mathrm{~m}^{3} / \mathrm{kWh}$ of electrical energy and heat.

- The last operational unit consumption of lubricating oil by the GE JENBACHER JMS 316 GS-B.LC Engine (oil topping up without replacement) is estimated at a level of $0.2 \mathrm{~g} / \mathrm{kWh}$, with the figure declared by the Supplier being $0.3 \mathrm{~g} / \mathrm{kWh}$.

- The operation of the GE JENBACHER JMS 316 GS-B.LC Engine Biogas Cogeneration Set brings about measurable energy, economic and ecologic benefits to the WARTA S.A. Waste Treatment Plant, by reducing practically to zero the atmospheric emission of methane-containing biogas (at the source of its generation). It has improved the energy management at the WARTA S.A. Waste Treatment Plant of Częstochowa, in terms of both electrical energy and heat, as well as the Treatment Plant's energy safety, as the Biogas Cogeneration Set is able to operate on an insular basis as a reserve supply source for the Treatment Plant, while preserving the technology parameters.

- As a result of the operation of the Biogas Cogeneration Set, the current operational costs of WARTA S.A. Waste Treatment Plant of Częstochowa have been substantially reduced owing to the reduction of electrical energy purchasing from external suppliers by over 50\%; the utilization of the heat generated by cogeneration for in-house purposes; the elimination of the purchase of Boiler Room fuel oils in an amount of approx. 40 tons/year; the entry to the "Green Energy" Manufacturers list and obtaining regularly URE "Certificates of Origin" for electrical energy produced in the OZE (estimated by the Operator at a level of more than 5,000 MWh), which have a material value at the Commodity Energy Exchange. pracy na poziomie $94,4 \%$, z wyjątkiem miesiąca lutego w którym zanotowano 142 godziny postoju oraz 64 jego uruchomienia wywołane zakłóceniami w zewnętrznej sieci elektrycznej.

- Zespół kogeneracyjny przepracował do 31.12.2009 r. 8450 godzin, produkując $\mathrm{w}$ tym czasie $6042,7 \mathrm{MWh}$ energii elektrycznej i 19 722,30 GJ (5478,42 MWh) ciepła, a pokrycie zapotrzebowania oczyszczalni na energię elektryczną i ciepło zostało pokryte własną produkcją odpowiednio w ok. $53 \%$ i $44 \%$.

- Średnie obciążenie elektryczne zespołu kogeneracyjnego podczas dotychczasowej eksploatacji wyniosło 0,715 MW, co stanowiło $86,4 \%$ jego obciążenia nominalnego, zaś średnie obciążenie cieplne - odpowiednio: 0,648 MW, i $74,5 \%$ jego obciążenia nominalnego.

- Średnia produkcja biogazu w OŚ WARTA S.A. w analizowanym okresie kształtowała się na poziomie 271,7 $\mathrm{m}^{3} / \mathrm{h}$, zaś zużycie biogazu przez zespół kogeneracyjny $250,5 \mathrm{~m}^{3} / \mathrm{h}$.

- Średnie jednostkowe zużycie biogazu w analizowanym okresie eksploatacji wyniosło $0,350 \mathrm{~m}^{3} / \mathrm{kWh}$ energii elektrycznej i $0,184 \mathrm{~m}^{3} / \mathrm{kWh}$ energii elektrycznej i ciepła.

- Dotychczasowe eksploatacyjne jednostkowe zużycie oleju smarującego przez silnik biogazowy GE JENBACHER JMS 316 GS-B.LC (uzupełnienia oleju bez wymian) kształtuje się na poziomie ok. $0,2 \mathrm{~g} / \mathrm{kWh}$, zaś deklarowane przez dostawcę w ofercie $-0,3 \mathrm{~g} / \mathrm{kWh}$.

- Eksploatacja biogazowego zespołu kogeneracyjnego z silnikiem GE JENBACHER JMS 316 GS-B.LC przynosi OŚ WARTA S.A. wymierne korzyści energetyczne, ekonomiczne i ekologiczne, redukując praktycznie do zera (u źródła jego wytwarzania) emisję do atmosfery biogazu zawierającego w swym składzie metan. Poprawiła ona gospodarkę energetyczną OŚ WARTA S.A., tak w zakresie energii elektrycznej jak i ciepła, a także bezpieczeństwo energetyczne oczyszczalni, ponieważ biogazowy zespół kogeneracyjny może pracować wyspowo jako rezerwowe źródło zasilania oczyszczalni z zachowaniem parametrów technologii.

- W wyniku eksploatacji biogazowego zespołu kogeneracyjnego zmniejszono znacząco bieżące koszty eksploatacji OŚ WARTA S.A. dzięki: ograniczeniu o ponad 50\% zakupu energii elektrycznej od dostawców zewnętrznych, zagospodarowywaniu na potrzeby własne całego ciepła wyprodukowanego $\mathrm{w}$ kogeneracji, zrezygnowaniu $\mathrm{z}$ zakupu oleju opałowego do kotłowni w ilości ok. 40 t/rok, uzyskano wpisu na listę producentów ,zielonej energii” i regularnemu pozyskiwaniu w URE „Świadectw pochodzenia" energii elektrycznej wyprodukowanej w OZE (szacowanej rocznie przez eksploatatora na ponad $5000 \mathrm{MWh}$ ), mające wartość materialną na Towarowej Giełdzie Energii.

Paper reviewed/Artykut recenzowany 


\author{
Abbreviation/Skróty i oznaczenia \\ IMTiTS PCz Instytut Maszyn Tłokowych i Techniki Sterowania \\ Politechniki Częstochowskiej \\ $\mathrm{CO}_{2}$ dwutlenek węgla \\ $\mathrm{CH}_{4} \quad$ metan \\ $\mathrm{H}_{2} \mathrm{~S} \quad$ siarkowodór
}

$\begin{array}{ll}\mathrm{H}_{2} & \text { wodór } \\ \mathrm{N}_{2} & \text { azot } \\ \text { KBN } & \text { Komitet Badań Naukowych } \\ \text { PSW WARTA } & \text { Przemysłowa Spółka Wodna WARTA } \\ \text { ZMiN WOLA Warszawa Zakłady Mechaniczne im. M. No- } \\ \text { wotki Warszawa }\end{array}$

\section{Bibliography/Literatura}

[1] Cupiał K., Dużyński A.: Dorobek Instytutu Maszyn Tłokowych i Techniki Sterowania Politechniki Częstochowskiej w dziedzinie konstrukcji, badań i eksploatacji silników gazowych. Materiały konferencyjne VII. Międzynarodowej Konferencji Naukowej SILNIKI GAZOWE 2006 - konstrukcja, badania, eksploatacja, paliwa odnawialne. s. 121-155, ZN PCz 162, Mechanika 26, Cz-wa 2006.

[2] Cupiał K., Dużyński A., Grzelka J.: Podsumowanie ośmioletniej eksploatacji biogazowego zespołu ciepło- i prądotwórczego w Oczyszczalni Ścieków WARTA S.A. w Częstochowie. A summary of the eight years of operation of the biogas heat and power-generating set in the Waste Treatment Plant of WARTA S.A. in Częstochowa. s. 71-81, Silniki Spalinowe $1 / 2006$ (124).

[3] Cupiał K., Dużyński A., Grzelka J.: Analiza możliwości zasilania silników spalinowych gazem generatorowym ze zgazowania osadów ściekowych. Materiały Konferencji naukowej Perspektywy zasilania biogazem silników spalinowych. Fundacja: Instytut Ochrony Środowiska i Energii Odnawialnej w Szczecinie. s. 27-37, Szczecin - Malmö Kristianstad 21-23.04.2009.

[4] Cupiał K., Dużyński A., Grzelka J., Bawor W.: Podsumowanie sześciomiesięcznej eksploatacji nowego biogazowego zespołu kogeneracyjnego w Oczyszczalni Ścieków WARTA S.A. w Częstochowie. Współczesne problemy energetyki gazowej i gazownictwa. Monografia pod redakcją Kaliny J., Kotowicza J., Skorka J., Walewskiego A. Energetyka Gazowa 2009. Wyd. Instytutu Techniki Cieplnej. Gliwice 2009. s. 415-436.

[5] Cupiał K., Dużyński A., Grzelka J., Mendera K.: Biogazowy zespół prądotwórczy o mocy elektrycznej $600 \mathrm{~kW}$ z utylizacją ciepła. Materiały Międzynarodowej Konferencji Silnikowej KONES'99. Journal of KONES - Internal Combustion Engines - Warszawa - Zakopane 1999, vol. 6, nr 3-4, Scientific Publication of Permanent Committee of KONES, Kraków, s. 30-37.

[6] Dużyński A.: Analiza rzeczywistych parametrów techniczno-eksploatacyjnych gazowych zespołów kogeneracyjnych.
Politechnika Częstochowska, seria Monografie nr 142. Częstochowa 2008. s. 335.

[7] Dużyński A.: Dwudziestoletnia historia konferencji naukowych Silniki Gazowe. Materiały konferencyjne VII Międzynarodowej Konferencji Naukowej Silniki Gazowe 2006 - konstrukcja, badania, eksploatacja, paliwa odnawialne. s. 215-238. ZN PCz 162, Mechanika 26, Częstochowa 2006.

[8] Kalmbach S., Schmölling J.: Technische Anleitung zur Reinhaltung der Luft - TA Luft. Schmidt Erich Verlag, 09/2004.

[9] Dziennik eksploatacyjny biogazowego zespołu kogeneracyjnego z silnikiem GE JENBACHER JMS 316 GS-B.LC za okres 12.2008-12.2009. Materiały wewnętrzne Oczyszczalni Ścieków WARTA S.A. w Częstochowie.

[10] GE JENBACHER Documentation JMS 316 GS-B/LC - wersja 2004.01.

[11] Instrukcja eksploatacji Centralnej Oczyszczalni Ścieków w Częstochowie. Biuro Projektowo-Handlowe EKOPROJEKT, Zabrze, 08.2008.

[12] Instrukcja techniczna nr 1000-0300. Jakość gazu pędnego. GE JENBACHER Documentation. 08.2005.

[13] Modernizacja gospodarki energetycznej i cieplnej z zastosowaniem odnawialnych źródeł energii na centralnej oczyszczalni ścieków eksploatowanej przez Oczyszczalnię Ścieków WARTA S.A. w Częstochowie. Zespół prądotwórczy. Projekt wykonawczy. II. Część technologiczna. BIPROWOD-Warszawa Sp. z o.o. Warszawa, luty 2008 r.

[14] Oczyszczanie gazu absorberami węgla aktywnego - JENBACHER Energie.

[15] Rynek Praw Majątkowych, www.tge.pl; www.polpx.pl, $02.2010 \mathrm{r}$.

[16] Schemat technologiczny Oczyszczalni Ścieków WARTA S.A. w Częstochowie. Materiały wewnętrzne Oczyszczalni Ścieków WARTA S.A. w Częstochowie.

[17] www.cire.pl/GE/, 06.2009 r.

[18] www.ekonaft.com.pl/mobil_last/przemyslowe-mobil/n06_do_ silnikow gazowych/full-mobil-pega-sus610.htm, $06.2009 \mathrm{r}$.

[19] www.wartasa.cze.pl, $02.2010 \mathrm{r}$.
Mr. Adam Dużyński, DEng. - Vice-director of the Institute of Internal Combustion Engines and Control Engineering at the Częstochowa University of Technology.

Drinż. Adam Dużyński-adiunkt, zastępca dyrektora Instytutu Maszyn Tłokowych i Techniki Sterownia Politechniki Częstochowskiej.

e-mail:duzynski@imc.pcz.czest.pl

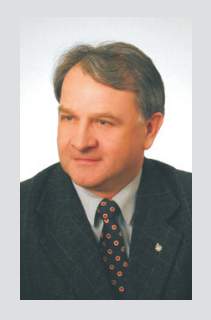

Mr. Wiesław Bawor, MSc., MEng. - senior specialist, WARTA S.A. Waste Treatment Plant in Czestochowa.

Mgr inż. Wiesław Bawor - starszy specjalista. Oczyszczalnia Ścieków WARTA S.A. w Częstochowie.

e-mail: wbawor@wartasa.cze.pl

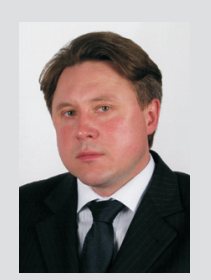

